ROCZNIKI KULTUROZNAWCZE

Tom XI, numer $2 \quad-\quad 2020$

DOI: http://dx.doi.org/10.18290/rkult20112-7

RAFAŁ JANCZAREK

\title{
FRYDERYK CHOPIN I FUREDERIKKU SHOPAN — RECEPCJA MUZYKI FRYDERYKA CHOPINA W KULTURZE JAPOŃSKIEJ
}

\section{MUZYKA SKRACAJĄCA DYSTANS}

W kilku zdaniach wprowadzenia zwróćmy uwagę na obecność europejskiej muzyki klasycznej w Japonii. Skąd się tam wzięła i jaki osiągnęła status na przestrzeni lat? Wyjaśniając, można posłużyć się metaforyczną opowieścią: Gdy wrota Meiji $i^{1}$ zostały otwarte, w kolejce do japońskiej enklawy ustawiło się grono europejskich i amerykańskich pielgrzymów. Chociaż pochód poruszał się płynnie, każdy pielgrzym musiał poczekać, aż nadejdzie jego kolej. Gdy wymarzona chwila wreszcie nastawała, zyskiwało się zgodę na zaprezentowanie swojej oferty. W zależności od oceny Japończyków, prezentowane wartości - po przetworzeniu - stawały się częścią istniejącej rzeczywistości bądź też nie uzyskiwały aprobaty i w gruncie rzeczy odrzucano je. Jakoby ignorując toczące się przed Japonią zbiorowisko, do kraju przeniknął niepozorny wędrowiec. Nie miał on do zaoferowania bogactw rewolucji przemysłowej, nie posiadał wiedzy na temat nowoczesnego prawa ani też nie był mędrcem sztuki uprawiania wojennego rzemiosła. Do zaproponowania miał jedynie dźwięki. Paradoksalnie to właśnie ten przybysz stał się gościem honorowym.

Mgr RAFAE JANCZAREK - doktorant UKSW w Warszawie; adres do korespondencji - e-mail: rafal.janczarek2@gmail.com. ORCID: https://orcid.org/0000-0002-8891-0433.

${ }^{1}$ Meiji jidai (jap. 明治時代) - okres w historii Japonii datowany od 1868 n.e. do 1912 n.e. Wraz z początkiem tej epoki Japonia została zmuszona do porzucenia sakoku (izolacji kraju). Meiji to czasy gwałtownej i wszechobecnej modernizacji Japonii na wzór zachodni w myśl zasady wakon yōsai. Zob. Japonia okresu Meiji, Od tradycji ku nowoczesności praca zbiorowa, red. Beata Kubiak Ho-Chi (Warszawa: Nozomi, 2006). Zob. też Conrad Totman, Historia Japonii, tłum. Justyn Hunia (Kraków: Wydawnictwo Uniwersytetu Jagiellońskiego, 2009), 366-458. 
Nietrudno wywnioskować, że ów niepozorny wędrowiec oraz jego twórczość z naszej opowieści były uosobieniem piękna i wzniosłości muzyki klasycznej, która zagościła w Japonii wraz z epoką Meiji ${ }^{2}$. Japończycy przyjęli go ciepło, gdyż są narodem niezwykle muzykalnym³ ${ }^{3}$. Dowodzi tego chociażby sytuacja po II wojnie światowej, tj. jednym z najtragiczniejszych okresów w historii. Po ostatecznej klęsce osi Rzym-Berlin-Tokio w Kraju Wschodzącego Słońca zagościł niepokój. Państwo znalazło się na krawędzi upadku: gospodarka uległa zapaści, miasta zamieniły się w pogorzeliska, zapanował głód, rozpowszechniały się epidemie, rozwijał się czarny rynek, a na dodatek odczuwalne były skutki promieniowania radioaktywnego ${ }^{4}$. W obliczu tak traumatycznych doświadczeń można by przypuszczać, że priorytetem stało się zaspokojenie podstawowych potrzeb, próba przetrwania. Niewiele jednak było potrzeba czasu, by piramida hierarchii potrzeb człowieka (w ujęciu Abrahama Maslowa ${ }^{5}$ ) uległa zachwianiu, a może nawet całkowitemu odwróceniu. Kiedy 15 sierpnia w 1945 r. w ocalałej z bombardowań tokijskiej hali Hibiya odbył się powojenny koncert europejskiej muzyki klasycznej, Japończycy gotowi byli zrezygnować ze swoich skromnych oszczędności na jego rzecz ${ }^{6}$. Spragnieni muzyki klasycznej byli nie tylko jej pasjonaci, ale i liczni zwykli obywatele - działo się to w czasach, gdy „brakowało wszystkiego: ryżu, herbaty, ryb, jarzyn i owoców"7 . Kōichi Hattori ${ }^{8}$ wspomina te wydarzenia w taki sposób:

[...] my bardzo pragnęliśmy słuchać pięknej muzyki, głównie klasyków zachodnich - Beethovena, Mozarta i Chopina. [...] I oto miłośnicy muzyki ustawiali się w długie kolejki po bilety, żeby z pustym żołądkiem słuchać 3 Symfonii Beethovena'.

\footnotetext{
${ }^{2}$ Ściślej rzecz ujmując, muzyka klasyczna przywędrowała do Japonii wcześniej. W 1549 r. do Kraju Kwitnącej Wiśni dotarły organy. Znamienna jest też działalność portugalskich misjonarzy, którzy uprzystępniali Japończykom muzykę Zachodu. Niemniej za sprawą izolacjonizmu ustanowionego przez Ieyasu Tokugawę i ogólnej niechęci władcy do tego, co niejapońskie, muzyka klasyczna nie rozwijała się. Zmieniło się to dopiero wraz z otwarciem kraju w epoce Meiji, kiedy to muzyka poważna na stałe zagościła w sercach Japończyków i już nigdy ich nie opuściła.

${ }^{3}$ Lech Zdzisław Niekrasz, Chopin gra w duszy japońskiej (Warszawa: Rytm, 2010), 17-30.

${ }^{4}$ Andrew Gordon, Nowożytna historia Japonii, tłum. Iwona Merklejn (Warszawa: Państwowy Instytut Wydawniczy, 2010), 310-401.

${ }^{5}$ Zob. Abraham MAsLow, Motywacja i osobowość, thum. Józef Radzicki (Warszawa: Wydawnictwo Naukowe PWN, 2006).

${ }^{6}$ Niekrasz, Chopin gra $w$ duszy japońskiej, 31.

${ }^{7}$ Ibid.

${ }^{8}$ Kōichi Hattori (ur. 1933) - japoński kompozytor, eseista i krytyk muzyczny.

${ }^{9}$ Za: Niekrasz, Chopin gra $w$ duszy japońskiej, 31.
} 
W podobny sposób Hattori opisuje również wystawienie Traviaty Verdiego, mające miejsce rok później:

Po upojeniu się pięknem scenografii, emanującej przepychem z połowy XIX wieku, Japończycy powracali do swoich nędznych domostw, jakie sklecili pośród ruin powalonego miasta. Bilet kosztował tyle, ile starczyłoby im na utrzymanie przez wiele dni ${ }^{10}$.

Naród, który stawia dorobek wielkich kompozytorów ponad potrzeby życiowe, z pewnością zasługuje na miano muzykalnego. Jeśli więc możemy powiedzieć, że muzyka skraca dystans, to niezaprzeczalnie stało się tak w przypadku Polski i Japonii. O ile Mozart, Beethoven czy Vivaldi symbolizują pojedyncze nitki łączące Europę z Japonią (z Austrią, Niemcami i Włochami), o tyle w przypadku Chopina zauważamy, że Japonię zespala z Polską kumihimo ${ }^{11}$. Kumihimo to japońska sztuka splatania ze sobą sznurków, a także określenie na plecionkę składającą się ze starannie wybranych sznurków. W dialogicznej sieci przeplatających się z sobą musubi $i^{12}$ to właśnie więź z polskim kompozytorem odznacza się najwyraźniej, i to do tego stopnia, że można postawiać tezę, iż jest to prawdziwy fenomen. Znamienny i zastanawiający pozostaje zatem fakt, że to właśnie romantyczna twórczość Chopina jest spajającym nasze kultury ogniwem. Masahiko Satō ${ }^{13}$, podejmując refleksję nad osobą dziewiętnastowiecznego kompozytora, zestawia specyfikę jego dorobku $\mathrm{z}$ haiku. Nici porozumienia upatruje $\mathrm{w}$ tradycji romantycznej:

Studiowałam tylko muzykę epoki romantyzmu, koncentrując się na Chopinie. Muzyka tego okresu w Europie wyrastała z historii różnych krajów i każdy z nich posiada swój własny romantyzm, który niewiele ma wspólnego z romantyzmem innego kraju. Na przykład romantyzm francuski wywodził się z rewolucji, która przyniosła wolność wyrażania myśli. Nie było zbyt wiele tej wolności w Niemczech i dlatego romantyzm niemiecki ma charakter odrębny. W Polsce, która doświadczyła trudnej przeszłości, zrodził się romantyzm bardzo oryginalny i przepojony humanizmem. Naród polski poznał prawdziwą wartość wolności i stąd taki właśnie charakter polskiego romantyzmu. Ponieważ Polacy znaleźli się w najtrudniejszej sytuacji politycznej, dlatego polski romantyzm wyrósł z poczucia i umi-

\footnotetext{
${ }^{10} \mathrm{Za}$ : ibid., 32.

${ }^{11}$ Kumihimo - jap. 組紐.

${ }^{12}$ Musubi (jap. 結び) to $\mathrm{w}$ dosłownym rozumieniu węzet, ale ten termin ma również znaczenie metaforyczne - odnosi się do przeplatających się z sobą nici, które symbolizują więzi między poszczególnymi bytami. Koncepcja świata według musubi zakłada, że wszystko jest $\mathrm{w}$ pewien sposób z sobą powiązane.

${ }^{13}$ Masahiko Satō (ur. 1941) - japoński pianista jazzowy, kompozytor i aranżer.
} 
łowania wolności. Myślę, że duch muzyki Chopina dąży do stworzenia właściwej formy oryginalnej ekspresji. [...] Piękno, które ukochał Chopin, wykracza poza obręb tradycji i rozkwita wszędzie. My, Japończycy, mamy tę samą tendencję. Haiku jest rodzajem japońskiego poematu, a każdy poemat ma swoją formę i swój styl. Dążenie do stworzenia odpowiedniego stylu i formy każdej oryginalnej ekspresji sprawia, że Japończycy tak bardzo rozumieją Chopina ${ }^{14}$.

Czerwona nić przeznaczenia ${ }^{15}$ łączy dwoje miłujących się ludzi analogicznie do romantycznej więzi miłosnej rozumianej jako intymny związek dwóch powołanych do współistnienia dusz. A jaki charakter ma więź łącząca Japonię i Polskę? Skoro łączącym nas kumihimo jest Fryderyk Chopin, automatycznie nasuwają się pytania dotyczące natury tego połączenia. Uleganie mitom i stereotypom, zwłaszcza takim, które budują dumę narodową określonej społeczności, to perspektywa, której często się ulega. Czy zatem mówimy tu o uwielbieniu, czy o umiarkowanym zainteresowaniu? Odpowiedź na to pytanie wymaga kulturoznawczego rozpoznania materii.

\section{NA TROPIE FENOMENU CHOPINA}

Z fenomenem mamy do czynienia, gdy doświadczamy jakiegoś - niekoniecznie ściśle skategoryzowanego - zjawiska, do którego nie sposób znaleźć żadnej analogii. Nie ogranicza się on wyłącznie do niepowtarzalności, lecz uzasadnia także szeroko pojętą recepcję i niesłabnące mimo upływu lat zainteresowanie. Fenomen Chopina w Japonii próbował już opisać Lech Zdzisław Niekrasz w książce pt. Chopin gra w japońskiej duszy ${ }^{16}$.

${ }^{14}$ Za: Niekrasz, Chopin gra w duszy japońskiej, 52.

${ }^{15}$ Unmei no akai ito (jap. 運命の赤い系) - czerwona nić przeznaczenia lub czerwona nić losu. Legenda o chińskich korzeniach, zaadoptowana również w Japonii (w nieco innej postaci). Wedle japońskiej wersji czerwona nić przeznaczenia łączy dwie dusze/dwóch ludzi, powołanych do miłości niezależnie od miejsca i czasu. Owa nić jest owinięta wokół małego palca kobiety i małego palca mężczyzny, nierozerwalnie łącząc ich ze sobą. Nie można jej ani ujrzeć, ani doświadczyć, niemniej cały czas istniej, i choć często może się rozciągać lub zapętlać, to jej zerwanie nie jest możliwe.

${ }^{16}$ Publikacja Niekrasza ma charakter publicystyczny, jest to dotychczas najobszerniejsze polskie kompendium wiedzy o recepcji muzyki Fryderyka Chopina w Japonii. Chociaż opinie, spostrzeżenia i relacje przytaczane przez Niekrasza w przeważającej mierze pochodzą z drugiej połowy XX wieku oraz początku wieku XXI, nie sposób odmówić im aktualności. Niekraszowskie obserwacje znajdują potwierdzenie nawet we współczesnych tekstach eseistycznych, reporterskich i popularnonaukowych autorstwa tak Japończyków, jak i Polaków. Dowodzą tego na przykład: Kazumi Ōshima, „Recepcja twórczości Chopina w Japonii”, 2008, tłum. Jerzy Ossowski, Chopin.pl, dostęp 19.10.2020, https://www.chopin.pl/np/w japonii.pl.html; Ewa KofIN, Ich słowa (Wrocław: Atut Oficyna Wydawnicza, 2009); Mariusz Herma, „Fryderyk o skośnym spojrzeniu”, 
Antropologia kulturowa zakłada, że jedną z najlepszych metod badawczych jest obserwacja. Abstrahuję od tego, czy stosowniejsze jest podejście dystansujące, to znaczy takie, w którym badacz pozostaje niejako zewnętrznym obserwatorem $\mathrm{w}$ stosunku do badanej społeczności (nie uczestniczy w jej życiu kulturowym), czy też podejście oparte na bliskości, kiedy badacz de facto staje się uczestnikiem obserwowanej rzeczywistości (bierze udział w jej życiu kulturowym); oba typy dostarczają rzetelnych informacji naukowych. Skorzystajmy z jej możliwości i przytoczmy relacje ludzi, którzy doświadczyli specyfiki odbioru muzyki w Japonii. Kazimierz Gierżod ${ }^{17}$ opisuje swoje doświadczenia w następujący sposób:

Jeśli ktoś interesuje się życiem muzycznym i zgłębi to, co dzieje się w salach koncertowych w Japonii, to oczywiście spotka się z Chopinem. Naturalnie, że programy japońskich koncertów zawierają dzieła wielu innych kompozytorów, i to głównie klasycznych, europejskich, ale Chopin zajmuje istotne miejsce w tych programach i można powiedzieć, że kiedy Japończycy słuchają bądź grają Chopina, to zainteresowanie ich jest rzeczywiście olbrzymie. I to nie tylko tych, którzy są profesjonalnie związani z muzyką, jak profesorowie czy ich uczniowie, ale też małe dzieci i ich rodzice. Na słowo Chopin wszystkim świecą się oczy! Może kilka przykładów... Miałem kiedyś koncert w Nagano, które jest znane z olimpiady. To jest duże miasto. [...] Po koncercie ludzie przychodzili, prosili o autografy i nawiązywali rozmowę. Trwało to jakieś pół godziny i wreszcie wiozą mnie do hotelu. Jest tam, jak dobrze pamiętam, duży ogrodzony parking i za tym parkingiem widzę thum ludzi, którzy czekają, żeby móc mnie jeszcze pożegnać. [...] Była to publiczność mojego koncertu. Stali i czekali pół godziny, bo wiedzieli, że będę odjeżdżał. [...] Podszedłem więc do nich i przez ogrodzenie podawaliśmy sobie ręce. Boże! Jak oni rzeczywiście kochają tego Chopina! Bo przecież chodziło o Chopina, a nie o moją skromną osobę. [...] Podobnych zdarzeń mógłbym przytaczać dziesiątki. [...] Oni grają też Bacha, grają Mozarta, Haydna i Beethovena, ale dźwięk słowa „Chopin” ich elektryzuje ${ }^{18}$.

Przekrój 2010, nr 6: 46-49 — dostępny również jako „Dlaczego Azjaci kochają Chopina (bardziej niż Polacy)", Ziemia Niczyja, dostęp 19.10.2020, https://www.ziemianiczyja.pl/ 2010/04/dlaczego-azjacikochaja-chopina/; Haruka TAKASAKA, „Harmonia, ulotność, Nintendo...”, thum. Wioletta LaskowskaSmoczyńska, Tygodnik Powszechny. Kwartalnik Chopinowski 04. Vivace 2010, nr 41: 8-9; Bernardyn, Piotr. „Japonia: Geniusz udomowiony”. Tygodnik Powszechny. Kwartalnik Chopinowski 02 2010, nr 31: 10; Shizuka OKumuRA, „Chopin w Japonii. O współczesnych gustach muzycznych Japończyków i ich miłości do Polskiego Kompozytora”, 2017, Meakultura. Muzyka, edukacja, artyści, dostęp 19.10.2020. http://mea kultura.pl/artykul/ chopin-w-japonii-o-wspolczesnych-gustachmuzycznych-japonczykow-i-ich-milosci-do-polskiego- kompozytora-1731.

${ }^{17}$ Kazimierz Gierżod (1938-2018) - polski pianista i pedagog muzyczny, profesor Uniwersytetu Muzycznego Fryderyka Chopina, a w latach 1987-1993 jego rektor (wówczas uczelnia nosiła nazwę Akademii Muzycznej im. Fryderyka Chopina w Warszawie). W 2000 r, Gierżod był jednym z jurorów - między innymi z Ikuko Endō - XIV Międzynarodowego Konkursu Pianistycznego im. Fryderyka Chopina.

${ }^{18}$ Za: NieKrasz, Chopin gra w duszy japońskiej, 49-50. 
$Z$ relacji Gierżoda wynika kilka istotnych faktów. Przede wszystkim trzeba zaznaczyć, że w Japonii każdy koncertowy, ważny repertuar pianistyczny poświęca twórczości Chopina dużo uwagi i miejsca ${ }^{19}$. Jedynie percepcja chopinowskiej muzyki odwołuje się do najgłębszych zakamarków japońskiej emocjonalności. Ma to miejsce zarówno w przypadku znawców, jak i miłośników europejskiej muzyki poważnej w ogóle. Do podobnych wniosków doszedł też Maciej Piotrowski ${ }^{20}$ :

Wystarczy popatrzeć na programy koncertów japońskich i zagranicznych pianistów i na programy nauczania w szkołach i na uniwersytetach, by stwierdzić, że Chopin zajmuje poczesne miejsce. [...] Chopin porusza $\mathrm{w}$ nich jakieś pokłady wrażliwości, których oni na co dzień nie okazują, i stąd, jak mi się wydaje, to ich uwielbienie, bo to tak trzeba nazwać, dla Chopina $[\ldots]^{21}$

Powyższa relacja poszerza zasięg oddziaływania fenomenu Chopina o szkolnictwo. Japońskie uczelnie, takie jak np. Kunitachi Ongaku Daigaku, Musahino Ongaku Daigaku czy też Tōkyō Ongaku Daigaku, interesują się badaną przez nas muzyką na tyle, że Niekrasz oznajmia, iż japońskie szkolnictwo muzyczne „Chopinem stoi”"22. Zarówno Gierżod, jak i Piotrowski zauważają, że polski kompozytor niepodzielnie króluje wśród preferencji japońskich wykonawców, kompozytorów, a także miłośników klasycznych dźwięków. Owa fascynacja narodziła się w epoce Meiji i pozostała nienaruszona do dzisiaj. Nieprzerwane zainteresowanie potwierdzają najróżniejszego rodzaju ankiety i plebiscyty. W 1991 r. cieszące się prestiżem czasopismo Ongaku no tomo zwróciło się do pianistów japońskich i zagranicznych z prośbą o wytypowanie dziesięciu najbardziej, ich zdaniem, popularnych wśród publiczności tokijskiej kompozytorów ${ }^{23}$. Głosy samych Japończyków rozłożyły się w następujący sposób: Brahms - 41 głosów, Schubert - 43 głosy, Ravel - 56 głosów, Bach - 59 głosów, Debussy - 69 głosów, Liszt - 70 głosów, Mozart - 104 głosy, Beethoven - 108 głosów, Schuman - 108 głosów, Chopin - 261 głosów. Po dodaniu zaś opinii zagranicznych kompozytorów konsensus przybrał taką postać: Brahms - 55 głosów, Ravel - 68 głosów, Bach - 69 głosów, Schubert - 72 głosy, Debussy - 84 głosy, Liszt - 98 głosów, Schuman - 130 głosy, Mozart - 155 głosów, Beethoven - 170 głosów, Chopin -324 głosy $^{24}$. W obu bitwach Chopin odniósł zwy-

\footnotetext{
${ }^{19}$ Ibid., 47-82.

${ }^{20}$ Maciej Piotrowski - profesor Uniwersytetu Muzycznego Fryderyka Chopina.

${ }^{21} \mathrm{Za}$ : NieKrasz, Chopin gra $w$ duszy japońskiej, 51-52.

${ }^{22}$ Ibid., 69-82.

${ }^{23}$ Ibid., 47

24 Ibid..
} 
cięstwo. Co znamienne, został on faworytem zarówno Japończyków, jak i obcokrajowców.

Relacje przytaczanych autorytetów pozwalają stwierdzić, że w ścisłej mierze dotyczą one wyłącznie płaszczyzn związanych z muzyką klasyczną. Nie sposób na ich podstawie wyprowadzać tez prowadzących do generalizacji. Przekonanie, że większość Japończyków nieprzerwanie uczestniczy w życiu kulturowym filharmonii i sal koncertowych, obfitowałoby w saidow$\mathrm{ski}^{25}$ orientalizm ${ }^{26}$. Nie pokrywałoby się ze stanem faktycznym. Czy zatem pojmujemy uwielbienie Chopina w odpowiednich kategoriach? W obliczu argumentacji naukowców i samych muzyków nie sposób kwestionować samego fenomenu, czemu jednak mielibyśmy uważać, że stykamy się z ewenementem na skalę krajową, nie zaś uwielbieniem w obrębie wysublimowanego grona koneserów? Może Chopin bardziej niż cesarza czy też dawnego shōguna przypomina władającego prowincją daimyo $\bar{o}^{27}$ ? Wprawdzie jego prowincja byłaby potężnie ufortyfikowaną, szczęśliwą krainą, ale wciąż pozostawałaby obszarem ograniczonym. $Z$ pomocą $w$ rozwianiu tych wątpliwości przychodzi nam obserwacja Ryszarda Jabłońskiego:

Sądzę, że najwyżej cenią Chopina. Może na drugim miejscu, jeśli chodzi o klasyków, postawiłbym Mozarta. Te dwa nazwiska zdecydowanie dominują w życiu muzycznym Japonii. Na jakiej podstawie tak sądzę? Otóż dlatego, że muzyka Chopina jest często grana $\mathrm{w}$ różnych wersjach nawet $\mathrm{w}$ pubach, klubach, kawiarniach czy restauracjach w tak dziwnych, co prawda, interpretacjach, że czasami trudno jest stwierdzić, że to nasz kochany Chopin. Jego muzyka, jak powiadam, jest tam dostępna wszędzie, wszędzie słuchana i grana. Mało tego, jest też śpiewana! Oni mają swoje teksty do wielu utworów Chopina ${ }^{28}$.

${ }^{25}$ Edward SAID, Orientalizm, tłum. Monika Wyrwas-Wiśniewska (Poznań: Wydawnictwo Zysk i S-ka, 2005).

${ }^{26} \mathrm{~W}$ rozumieniu Saida termin orientalizm odnosi się do ideologiczno-opresyjnej „konstrukcji poznawczej" świata Zachodu, jest czymś na kształt spreparowanej soczewki, przez którą dokonuje się oglądu kultur określanych przez Europejczyków jako egzotyczne. Zdaniem myśliciela kultury ugruntowane na dorobku cywilizacji europejskiej tak naprawdę nie dążą do poznania kultur wywodzących się z innych kanonów. Kreują natomiast — nierzadko na potrzeby własnego imperializmu - wypaczony, odpowiadający własnym upodobaniom, obraz rzeczywistości. Orientalizm można zatem określić jako fałszywą świadomość lub fałszywe poznanie (przynajmniej w odniesieniu do „egzotyki”). Uprawianie orientalizmu nie zawsze odbywa się świadomie, nierzadko jest nieświadomym błędem, wynikającym z niewiedzy tudzież lenistwa intelektualnego, braku umiejętności odróżnienia stereotypu od prawdy.

${ }^{27}$ Daimyō (jap. 大名) — pojęcie wieloznaczne, którego rozumienie jest zależne od okresu historycznego, na przykład w czasach Edo daimyō byli kimś na kształt zarządców prowincji podległych shogunatowi.

${ }^{28}$ Za: NieKrasz, Chopin gra w duszy japońskiej, 48. 
W przeciwieństwie do wcześniejszych spostrzeżeń Jabłoński zwraca uwagę na ciekawy aspekt kulturowy. Dowiadujemy się oto, że muzyka Chopina wcale nie jest ograniczona do sal koncertowych. Przeciwnie, jest dostępna w miejscach, które nie mają nic wspólnego z kulturą wysoką ${ }^{29}$. Innymi słowy, dorobek pianisty zaznacza swą obecność w sferze tzw. kultury popularnej, a ponadto jest przez nią przetwarzany, a zatem interpretowany i przyswajany na nowo, inaczej niż w tradycyjnym tego słowa znaczeniu. Owa wszechobecność świadczy o ekspansywności Chopinowskiej twórczości, a przejawia się to w najróżniejszych płaszczyznach społeczno-kulturowych.

Oddajmy głos Japończykom i sprawdźmy, czy ich opinie pokrywają się z osądami Polaków. Yūmi Tōyama ${ }^{30}$ ocenia sprawę w taki sposób:

Chopina słuchają nawet ci, którzy w ogóle nie słuchają muzyki, ponieważ jego muzyka ma taki specyficzny image. Ludzie, którzy nie są muzykami znają Chopina, chociaż często w ogóle nie wiedzą, że to Chopin. [...] Gdzie można spotkać muzykę Chopina? Ach, to jest dobre pytanie! Owszem, na koncertach i recitalach, ale również w takich miejscach, jak hotelowe lobbies, kawiarnie czy bary, gdzie ludzie spotykają się na drinku. [...] Polacy się dziwią, że Japonia jest tak daleko, a mimo to muzykę Chopina usłyszeć tam można wszędzie $[\ldots]^{31}$

Wedle socjologów słowa przeistaczają się w fakty poprzez skonfrontowanie ich z określoną, najlepiej generującą dane liczbowe, materią. A jak to wygląda w przypadku recepcji Chopina? Zacznijmy od tego, że odcisnął on swe piętno na rynku fonograficznym - co niekoniecznie budzi zdziwienie - wydawniczym oraz telewizyjno-radiowym. „Rozległość” fonograficznego mikrokosmosu w Japonii to aspekt przekraczający najśmielsze oczekiwania Polaków. Znajdziemy w nim tak enkę ${ }^{32}$ i $J$-pop ${ }^{33}$, jak również zachodnie przeboje i muzykę klasyczną. Wytwórcy, by wspomnieć chociażby EMI Records Ltd i Nippon Columbia Co. Ltd, oferują tak wieloraki asortyment muzyczny — dostępne są utwory z każdej epoki, każdego możliwego stylu oraz w każdym możliwym wykonaniu - że próba syntetycznego uogólnienia fenomenu płytowego graniczy z cudem:

\footnotetext{
${ }^{29}$ Podział kultury na kulturą wysoką i kulturę masową jest stosowany w kulturze europejskiej. W kulturze Japonii taka klasyfikacja właściwie nie istnieje, ewentualnie można uznać, że granica między dwiema kulturami jest bardzo płynna i elastyczna.

${ }^{30}$ Yūmi Tōyama - japońska pianistka klasyczna. Zob. https://yumitoyama.wordpress.com/.

${ }^{31}$ Za: Niekrasz, Chopin gra $w$ duszy japońskiej, 48-49.

${ }^{32}$ Enka (jap. 演歌) - tradycyjna pieśń japońska o melancholijnym charakterze. Współcześnie pojęcie uległo przeobrażeniom, a enka stała się odrębnym rodzajem muzyki popularnej.

${ }^{33} J$-pop (jap. ジェイポップ; Jeipoppu) - Japanese pop, stosunkowo młody termin, określający japońską muzykę popularną (z wyjątkiem enki). Pojęcie to zostało wypromowane przez Radio J-Wave i zastąpiło kategorię kayōkyoku, która oznaczała ni mniej, ni więcej muzykę rozrywkową.
} 
O zaspokojenie zróżnicowanych gustów muzycznych zabiegają dziesiątki wytwórni płytowych, w tym EMI Records Ltd., Mercury Music Entertainment Co. Ltd., Nippon Columbia Co. Ltd., Polygram K.K., Sony Music Entertainment (Japan) Inc., Toshiba EMI Ltd., czy War Music Japan, by ograniczyć się do kilku tych największych i najbardziej ekspansywnych. Specjalnością niektórych wytwórni płytowych są całe serie z muzyką klasyczną, jak Crown Classics, Victor Classics czy Canyon Classics w wykonaniu muzyków japońskich i zagranicznych ${ }^{34}$.

Karkołomne byłoby ustalenie liczby płyt zawierających utwory Chopina. Można jedynie pozwolić sobie na wytypowanie najbardziej znamiennych wykonań, choćby płyty Ikuko Endō plays Chopin ${ }^{35}$, które ze względu na osobę artysty stały się powszechnie rozpoznawalne ${ }^{36}$. Warto zaznaczyć, że Japończycy doskonale znają wykonania Chopina autorstwa światowej sławy pianistów z Polski, czego najlepszym przykładem jest chociażby dobra znajomość twórczości Rafała Blechacza.

Podobną inwazyjnością, gdy chodzi o Chopina, odznacza się także wspomniana już sfera radiowo-telewizyjna oraz świat książki. Ponad 200 prywatnych stacji nadaje muzykę polskiego kompozytora ${ }^{37}$. Na rynku wydawniczym sukcesywnie pojawiają się kolejne teksty literackie - mowa zarówno o tłumaczeniach z języka polskiego (na przykład Chopin Jarosława Iwaszkiewicza, wydany w 1979 r., Życie Chopina Kazimierza Wierzyńskiego, wydane w 1979 r. czy nawet Korespondencja Fryderyka Chopina 1831-1839, wydana w 2012 r.) i języków europejskich (chociażby Chopin Camille'a Bourniquela, wydany w 1980 r., czy Chopin vu par ses élèves Jeana-Jacques'a Eigeldingera, wydany w 2020 r.), jak i o rodzimych publikacjach, takich jak Shopan no shōzō Kikuo Kojimy, wydany w 1984 r., Shopan ga hiketa Michiko Ino, wydane w 1987 r., czy też Nihonjin to Shopan. Yōgaku dōnyūki no piano ongaku Junichiego Tady, wydane w 2014 r. $^{38}$ Ciekawostką jest ukazujący się od 1984 roku periodyk Shopan ${ }^{39}$, poświęcony wyłącznie życiu i twórczości kompozytora.

\footnotetext{
${ }^{34}$ Niekrasz, Chopin gra $w$ duszy japońskiej, 54.

${ }^{35}$ Ibid., 54.

${ }^{36}$ Ikuko Endō zasłynęła m.in. dzięki swojemu występowi w VIII Międzynarodowym Konkursie Pianistycznym im. Fryderyka Chopina w Warszawie w 1970 r. Otrzymała wówczas wyróżnienie Ministerstwa Kultury i Sztuki. Od tego momentu jej osoba często bywała kojarzona z Chopinem. W 2000 r, była jednym z jurorów XIV Międzynarodowego Konkursu Fryderyka Chopina w Warszawie, natomiast w 2015 r. została odznaczona Krzyżem Oficerskim Orderu Zasługi RP przez prezydenta Bronisława Komorowskiego.

${ }^{37}$ Niekrasz, Chopin gra $w$ duszy japońskiej, 54.

${ }^{38}$ Ibid., s. 58.

${ }^{39}$ Shopan (jap. ショパン) - Chopin.
} 
Skala japońskiej fascynacji Chopinowską „poezją dźwięku” nie ogranicza się tylko do Japonii. Egzemplifikacją tego stwierdzenia jest Międzynarodowy Konkurs Pianistyczny im. Fryderyka Chopina, jeden z najbardziej prestiżowych konkursów muzycznych na świecie. Artyści z całego świata przybywają do Polski, by konkurować ze sobą. Mieszkańców Zachodu nie dziwi już obecne na nim liczne grono Japończyków. Japońscy uczestnicy, jurorzy, widzowie, marketingowcy oraz fundatorzy pozaprogramowych nagród kreują tożsamość wydarzenia, nadając mu unikatowy charakter. Już podczas XII edycji konkursu w 1990 r. liczebność przybyszów z Japonii była tak duża, że polska prasa nie poskąpiła swym czytelnikom mniej lub bardziej rzetelnych relacji. W Expressie Poznańskim było można przeczytać następujące słowa:

Odwróćmy się na chwilę od estrady i spójrzmy na salę z publicznością. Na pierwszy rzut oka mogłoby się wydawać, że ten Konkurs odbywa się w Tokio lub Nagasaki - tylu tu Japończyków w rzędach ${ }^{40}$.

\section{Z kolei Gazeta Wyborcza komentowała:}

Może szkoda, że nie pozwolono Japończykom na wykupienie całej Sali - i tak mówi się w kuluarach, że następny Konkurs odbędzie się w Tokio ${ }^{41}$.

Mimo to o randze danego wydarzenia w określonym kręgu kulturowym nie świadczy wyłącznie zainteresowanie, ogólnoświatowy prestiż czy też aprobata ze strony obecnych słuchaczy. Najistotniejszy jest przede wszystkim temat - osoba i twórczość bohatera konkursu. Czy Międzynarodowy Konkurs Pianistyczny im. Fryderyka Chopina znaczy dla Japończyka więcej niż jakikolwiek inny konkurs muzyczny o międzynarodowym prestiżu? Odpowiedzi udziela Takako Takahashi, pianistka, która zdobyła piątą nagrodę w XII edycji konkursu z 1990 r. Rok wcześniej Takako otrzymała drugą nagrodę za najlepsze wykonanie utworu współczesnego w Międzynarodowym Konkursie Pianistycznym De Cidade do Porto w Portugalii, jednakże jak sama wyjaśnia - zwycięstwo to nie przyniosło jej sławy ${ }^{42}$. Sytuację zmienił dopiero Konkurs Chopinowski. Gdy po uzyskaniu piątej nagrody pianistka wróciła do ojczyzny, praktycznie z dnia na dzień stała się znaną osobistością. Otrzymała wiele propozycji koncertowania, a finalnie odbyła tournée po swoim kraju — zagrała dwadzieścia jeden recitali w ciągu

\footnotetext{
${ }^{40}$ Za: NieKRASZ, Chopin gra w duszy japońskiej, 114.

${ }^{41}$ Za: ibid., 115.

${ }^{42}$ Ibid., 143.
} 
miesiąca, co w praktyce oznaczało, że można ją było usłyszeć w całej Japonii niemalże codziennie ${ }^{43}$.

Skoro muzyka Chopina grana jest wszędzie, począwszy od sal koncertowych i uczelni muzycznych, skończywszy na barach i lokalach o całkiem rozrywkowym przeznaczeniu, kwestionowanie japońskiego fenomenu polskiego kompozytora byłoby oczywistym błędem. Japończycy potrafią nawet zaśpiewać Chopina. Wspomnijmy tutaj o karaoke. Słowo karaoke zazwyczaj zapisuje się przy użyciu katakany (jap. カラオケ), ale niekiedy też znaku kanji i katakany (jap. 空オケ). Kara (jap. カラ/空) w niniejszym pojęciu oznacza 'pustkę ${ }^{44}$ (etymologia nawiązuje do słowa karappo ${ }^{45}$, tzn. 'pusty' ${ }^{46}$ ), natomiast oke (jap. オケ) to skrót od wyrazu ōkesutora (jap. オーケストラ), który oznacza 'orkiestrę'. W literalnym przekładzie karaoke możemy przetłumaczyć jako "pustą orkiestrę, 47 . Po uwzględnieniu kontekstu kulturowego wiadomo, że chodzi tutaj o formę muzycznej ekspresji bez udziału instrumentów - innymi słowy, karaoke polega na śpiewie, zaśpiewaniu określonej piosenki, teledysku czy też właśnie utworu klasycznego ${ }^{48}$. Nie przywołuję karaoke bez wyraźnego powodu. Społeczeństwo Kraju Wschodzącego Słońca upodobało sobie wyrażenie śpiewem tego, co spoczywa w zakamarkach duszy. Nie byłoby przesady w stwierdzeniu, że każdy Japończyk doświadczył karaoke, naturalnie nie wszyscy w nim gustują, niemniej jego popularność $\mathrm{z}$ powodzeniem można zestawiać $\mathrm{z}$ poczytnością mangi. Podczas śpiewu nie jest ważny talent, predyspozycje muzyczne mają marginalne znaczenie ${ }^{49}$, najistotniejsze jest to, aby przelać swoje serce w śpiew ${ }^{50}$, wydobyć to, co niewyrażalne w innym języku. „Symboliczny obrządek” zwykle odbywa się w karaoke boxach ${ }^{51}$, czyli pomieszczeniach wyposażonych w umożliwiający odtworzenie dowolnego akompaniamentu sprzęt

\footnotetext{
${ }^{43}$ Ibid., 143.

${ }^{44}$ Alex ADLER, The World of Kanji: A Book to Learn 2136 Japanese Characters through Real Etymologies (CreateSpace Independent Publishing Platform, 2018), 486.

${ }^{45}$ Karappo - jap. 空っぽ.

${ }^{46}$ Dubravak Ugrešić, Kultura karaoke, tłum. Dorota Jovanka Ćirlić (Kraków: ha!art, 2013).

${ }^{47}$ Ibid.

${ }^{48}$ Japończycy nierzadko tworzą własne teksty do utworów klasycznych.

${ }^{49}$ Nie oznacza to, że predyspozycje muzyczne nie są mile widziane. Piękne odśpiewanie utworu zawsze pozostawia lepsze wrażenie niż kakofonia. Niemniej nawet najgorszy jazgot, jeśli jest pełen osobistych uczuć i starań, jawi się w karaoke niczym poezja.

${ }^{50}$ Istnieje popularny zwrot używany przez Japończyków w sytuacjach, gdy ,przelewają swoje serce" w podejmowane działania. Brzmi on kokoro wo komete (jap. 心を込めて).

${ }^{51}$ Karaoke box (jap. カラオケボックス — karaoke bokkusu), niekiedy thumaczone jako kabina do karaoke.
} 
audiowizualny. Uczestnicy śpiewają wówczas do wybranego przez siebie podkładu. Karaoke cieszy się sympatią każdej grupy społecznej, niezależnie od wieku, wykonywanej pracy czy wykształcenia, toteż z jego dobrodziejstw z powodzeniem korzystają na przykład uczniowie szkól, pracownicy biurowi czy emeryci. Przystępując do zbadania muzycznego życia Japonii, fundamentalnym aspektem nie jest wizytacja filharmonii, lecz wniknięcie w przestrzeń ludowej ekspresji dźwięków. W mojej ocenie brak przynależności do świata karaoke symbolizuje wykluczenie z japońskiej kultury muzycznej. Gdy naród śpiewa, co mu w duszy gra, wyraża sam siebie, swój charakter, swoją naturę. Czy Japończycy nagminnie śpiewają Chopina na karaoke? Dominuje - nierzadko związany z anime i mangą $-J-p o p^{52}$, aczkolwiek nie świadczy to o tym, że polski kompozytor nie ma dostępu do tego świata. Przeciwnie, pojawia się również tam, choć nie tak intensywnie jak w innych przestrzeniach muzycznej aktywności Japończyków. Ta sytuacja nie jest zwiastunem klęski lub pozornej kruchości poszukiwanego fenomenu. Już sam fakt uzyskania stałego dostępu ${ }^{53}$ do tak nietypowej, odwołującej się do stanów emocjonalno-intelektualnych, materii jest wyznacznikiem niezwykłości. Jeśli coś zaistnieje ${ }^{54} \mathrm{w}$ karaoke, to znaczy, że na stałe zakorzeniło się w sercach Japończyków, a muzyki wyrastającej głęboko z kategorii ${ }^{55}$ Nihonjin no kokoro ${ }^{56}$ nie sposób wykorzenić.

\section{CHOPIN ODARTY Z POLSKOŚCI ${ }^{57}$}

Czy Japończycy kochają Polskę? Czy polskość ich fascynuje? Jak wyjaśnić tę wyjątkową skalę Chopinowskiej potęgi w Japonii? Fascynacja inną niż rodzima kultura, bo z taką sytuacją niewątpliwie się tu mierzymy, rodzi

\footnotetext{
${ }^{52} \mathrm{~W}$ karaoke może rozbrzmiewać, i rozbrzmiewa, każda muzyka, prym wydaje się wieść jednak $J$-pop

53 „Stały dostęp” sygnalizuje, że Chopin ciągle pojawia się w przestrzeni karaoke. Gusta muzyczne Japończyków są dynamiczne, a moda przemija w Japonii wyjątkowo szybko. Utwór popularny i śpiewany na karaoke w określonym tygodniu może zostać zapomniany z początkiem następnego tygodnia.

${ }^{54}$ Zaistnieje, tzn. pojawi się i będzie ciągle obecne.

${ }^{55}$ Hayao KawaI, Japanese Psyche: Major Motifs in the Fairy Tales of Japan, thum. Sachiko Reece (Woodstock, CT: Spring Publications, 1997).

${ }^{56}$ Pojęcie Nihonjin no kokoro można przetłumaczyć jako serce (pojmowane metafizycznie) Japończyków. Jest ono kategorią fillozoficzno-psychologiczną i zarazem centralną dla całej japońskiej kultury, stanowi źródło m.in. ukochanego przez Japończyków emocjonalizmu.

${ }^{57}$ Przez polskość należy rozumieć wszelkie cechy dystynktywne składające się na charakter narodowy i kulturę Polaków.
} 
się przede wszystkim w dwóch przypadkach. W pierwszym z nich artykułuje się szeroko rozumiana inność. Kiedy człowiek doświadcza nowej kultury, a ta jest oparta na odmiennych kanonach wartości niż jego narodowa, musi przybrać wobec niej określoną postawę: postawę obojętną, postawę wrogości i nieufności lub postawę aprobaty i serdecznego przyjęcia. Obojętność następuje, gdy jednostka rezygnuje z refleksji nad nierodzimą kulturą, często zbyt „obcą” i niezrozumiałą. Wrogość i nieufność jest wynikiem ksenofobii oraz lęku przed wszystkim, co obce, nie dopuszcza się wówczas możliwości istnienia społeczności interpretujących świat inaczej od reprezentowanych przez rodzimość wzorców - niedopuszczalne byłoby przypuszczać, że obcy model mógłby okazać się „lepszy”. Innym powodem przybrania takiej postawy jest również wewnętrzna niezgoda człowieka na reprezentowany przez daną kulturę kognitywistyczny obrazu świata, np. ortodoksyjny chrześcijanin nigdy nie zaakceptuje uwarunkowań panujących w obrębie cywilizacji radykalnego islamu bądź reżimu północnokoreańskiego - i odwrotnie. Postawa aprobaty rodzi się wraz $\mathrm{z}$ dostrzeżeniem w innej kulturze elementów nieobecnych $\mathrm{w}$ narodowym kontekście albo kiedy kognitywistyczny model danej wspólnoty przedstawia propozycję odmienną od tej znanej jednostce, ale też niebędącą negacją wyznawanego przez nią systemu wartości. Wraz $\mathrm{z}$ aprobatą następuje chęć nawiązania dialogu i bliższego poznania. Aprobata może, ale nie musi, przeistoczyć się w serdeczne przyjęcie. Dzieje się tak $\mathrm{w}$ momencie, gdy człowiek — w zgodzie $\mathrm{z}$ wyznawanymi przez siebie wartościami $^{58}$ - dochodzi do wniosku, że oto znalazł to, czego od zawsze szukał. Przysposabia sobie propozycje danej kultury i kontrastuje je ze swoimi dawnymi normami, które jawią mu się w kategoriach krótkowzroczności i nierzadko ograniczeń ${ }^{59}$. Zarówno poziom aprobaty, jak i poziom serdecznego przyjęcia są płaszczyznami, na których przejawia się fascynacja.

Drugi przypadek fascynacji - opozycyjny do pierwszego — nie akcentuje różnic, lecz podobieństwa. W innej kulturze odnajduje się to, co łączy ją z naszą, niekiedy nawet pozostaje bardzo bliskie. Skutkuje to przekonaniem o rezonowaniu kultur, które niejako się uzupełniają.

Skoro tak, to czy poziom polonistycznej wiedzy - albo przynajmniej wiedzy o polskim romantyzmie w muzyce - Japończyków jest wprost proporcjonalny do zainteresowania osobą kompozytora? Czy w obrębie kultury Kraju Kwitnącej Wiśni „króluje” polska literatura, polski film, bądź polskie gry

\footnotetext{
${ }^{58}$ Nie muszą być one tożsame z wartościami narodowymi.

${ }^{59}$ Krótkowzroczność oznacza tutaj nieumiejętność dostrzeżenia przez własną kulturę tego, co w przekonaniu jednostki najważniejsze, najistotniejsze.
} 
komputerowe? Bynajmniej, polska kultura nie jest przedmiotem wyjątkowej uwagi Japończyków. Wiedza przeciętnego Japończyka o Polsce nie jest większa od wiedzy przeciętnego Polaka o Japonii. Co więcej, poza Chopinem (ewentualnie jeszcze Andrzejem Wajdą, Stanisławem Lemem i Wiedźminem $I I I^{60}$ ) przejawy polskiej kultury sytuują się na „uboczu” japońskich zainteresowań - eufemizując: cieszą się umiarkowanym zainteresowaniem na tle niejapońskich wytworów intelektualnych. Dedykuje się je w głównej mierze pasjonatom polskiej kultury oraz japońskim polonistom i slawistom; z pewnością nie dominują w tzw. głównym obiegu ${ }^{61}$. To dziwi, albowiem wydawać by się mogło, że fascynacja Chopinem powinna mieć swoje źródło w fascynacji polską kulturą.

Próba odpowiedzi na pytanie, dlaczego Chopin jest popularny w Japonii, to niełatwe zadanie. W znanych mi polskojęzycznych publikacjach nie pada jednoznaczne, rozbudowane wyjaśnienie tej kwestii. Niekrasz, śledząc Chopinowski fenomen, również próbował stawić czoła wyzwaniu odnalezienia jego umotywowania. Szukał odpowiedzi zarówno u polskich znawców muzyki klasycznej w Japonii, jak i samych Japończyków. Uzyskał zróżnicowane i niedookreślone wyniki, padała m.in. następująca argumentacja:

[...) Chopin jest im bardzo bliski, bo wbrew pozorom Japończycy w głębi duszy są sentymentalni. I chociaż nie uzewnętrzniają swoich uczuć, to jednak Chopin musi jakąś strunę $w$ nich poruszać, $i$ to taką bardzo intymną. Chopin porusza w nich jakieś pokłady wrażliwości, których oni na co dzień nie okazują i stąd, jak mi się wydaje, to ich uwielbienie, bo tak trzeba nazwać, dla Chopina $[\ldots]^{62}$

Muzyka Chopina trafia do nas poprzez swą melancholię i liryzm, a jednocześnie poprzez dramatyzm. Dlatego Chopin przemawia nam prosto do serca ${ }^{63}$.

Chopin jest popularny w Japonii od czasów przedwojennych. Polacy często mnie pytają, dlaczego Chopin jest tak uwielbiany w Japonii, ale ja nie wiem, co im

${ }^{60}$ Mowa o trzeciej części gry (Wiedźmin III: Dziki Gon), nie zaś o prozie Sapkowskiego.

${ }^{61}$ Zob. Bożena MACHIDA i Małgorzata SuZuKI, „Soplicowo zimą - wywiad z Yukio Kudō”, 2001, Strona polska w Japonii, dostęp 19.10.2020, http://www.klikdotsystems.jp/ stronapolska/ files/wywiad.html; Kōichi KuYAma, „O pracach translatorskich Yukio Kudo autora japońskiego przekładu 'Pana Tadeusza'", Wiek XIX: Roczniki Towarzystwa Literackiego imienia Adama Mickiewicza” 2 (44) 2009: 198-216; Tokimasa SEKIGUCHI, Eseje nie calkiem polskie (Kraków: Universitas, 2016); Ryszard ZAJĄCZKOWsKI, „Literatura polska w Japonii”, Roczniki Kulturoznawcze 7 (2016), nr 3: 147-169; TENŻE, „Japońska Polska. Kulturowy wizerunek Polski w Japonii”, Zeszyty Naukowe KUL 60 (2018), nr 2 (242): 381-398; „Prof. Akiko Kasuya: Polacy i Japończycy pobodnie czują i myślą", 2019, Dzieje.pl. Portal historyczny, dostęp 19.10.2020, https://dzieje.pl/kultura-i-sztuka/prof-akiko-kasuya-polacy-i-japonczycy-podobnieczuja-i-mysla.

${ }^{62} \mathrm{Za}$ : NiEKrasz, Chopin gra $w$ duszy japońskiej, 51-52.

${ }^{63}$ Ibid., 48 
odpowiedzieć. Może to ten żal płynący z serca? [...] Japończyk lubi śpiewać i prawie każdy utwór Chopina możemy zaśpiewać. [...] To jest kwestia tej bardzo bliskiej muzyce japońskiej śpiewności, cantabile. Piękna fraza, piękna harmonia, piękna rytmiczność i Japończycy wszystko to kochają $[\ldots]^{64}$

Fenomen popularności Chopina w Japonii jest czymś tyleż powszechnie znanym, co i trudno zrozumiałym. [...] Skłania to jednocześnie do podjęcia prób znalezienia [...] umotywowania. Myślę, że to charakterystyczny dla muzyki Chopina arystokratyzm ducha, spotykając się z wysublimowaną japońską wrażliwością emocjonalną, kształtowaną przez wielowiekowy obyczaj i kulturę duchową, staje się przyczyną tak silnego rezonansu... ${ }^{65}$

Dlaczego muzyka Chopina jest tak popularna w Japonii? Co stanowi o wysokiej ocenie tej muzyki przez naszych pianistów? Gdzie kryje się powab, jaki odnajdują w muzyce Chopina grający na fortepianie amatorzy oraz delektujący się nią słuchacze? Skupię się na próbie znalezienia odpowiedzi na ostatnie z tych pytań. Popularność muzyki Chopina wśród Japończyków bierze się z właściwego jej uroku. Typowe tylko dla fortepianu piękno dźwięków, naturalne pasmo melodyczne jak przy wykonaniu bel canta, świetlistość i improwizacja pasaży, szlachetność i delikatność ekspresji, słowem jest to muzyka fantazji i smutku. Nie tylko Japończyków, ale i innych ludzi na świecie fascynują te właściwości muzyki Chopina. $[\ldots]^{66}$

Chciałbym pokusić się o hipotezę dotyczącą psychicznego odbioru muzyki Chopina. My, Japończycy, jesteśmy wyposażeni w pewien rodzaj głębi psychicznej, którą bez udziału świadomości porusza pulsujące u podstaw tej wspaniałej i genialnej muzyki poczucie melancholii, osamotnienia oraz żalu. Mentalność ta, jak jestem skłonny sądzić, cechuje nas, Japończyków, wiążąc się z japońską świadomością społeczną i estetyczną ${ }^{67}$.

Powyższe odpowiedzi - wbrew pozornej rozpiętości - stanowią połowę sukcesu w poszukiwaniach przyczyn fascynacji Chopinem. Dla kulturoznawcy i muzykologa są oczywiście niesatysfakcjonujące, ale zawierają w sobie ważne informacje. Mianowicie daje się w nich zauważyć, że umotywowania uwielbienia dla Chopina poszukuje się raczej nie w osobie samego kompozytora, tym bardziej nie w szeroko pojętej polskości, lecz w paradygmatach i wrażliwości kultury japońskiej ${ }^{68}$. Taki wniosek początkowo

\footnotetext{
${ }^{64}$ Ibid., 51.

${ }^{65}$ Ibid., 53.

${ }^{66}$ Ibid., 184.

${ }^{67}$ Ibid., 188 .

${ }^{68}$ Ten wniosek jest również wynikiem osobistych studiów nad kulturą japońską, zwłaszcza dyskursem Nihonjinron. Osobny wątek stanowi kwestia uniwersalistyczno-esencjalistycznego potencjału muzyki samego Chopina. Sentymentalizm, melancholia, smutek, emocjonalizm, duchowa ekspresja, harmonia - to tylko niektóre, bardzo atrakcyjne dla Japończyków, właściwości
} 
wydaje się dyskusyjny, jak bowiem można mówić o Chopinie bez Polski? Przystępując jednak do pracy nad kulturą japońską, nie wolno zapominać o tak fundamentalnych aspektach, jak wakon yōsai ${ }^{69}$, twórcze naśladownictwo $^{70}$, czy też synkretyczna zdolność do łączenia w harmonijną całość pozornie przeciwstawnych ze sobą elementów:

Z eklektycznością kultury japońskiej wiąże się również jej synkretyczna natura, czyli łączenie w harmonijną całość często przeciwstawnych wzorców i elementów. Japończycy, aby móc tak intensywnie czerpać z innych kultur, muszą odznaczać się otwartością, tolerancją i umiejętnością godzenia sprzeczności ${ }^{71}$.

Z powodu tej wyjątkowości szlaki poszukiwania źródła Chopinowskiego fenomenu są zwodnicze - cały wcześniejszy wykład o genezie fenomenu spełnia swoje zadanie jako uniwersalne narzędzie służące badaniom w obrębie kultur europejskich, zastosowanie go jednak do Japonii sprowadza kulturoznawczy ogląd na bezdroża. Kluczem do Nihonjin no kokoro bynajmniej nie jest romantyzm ani też jakikolwiek inny okres z polskiej historii. Tylko japońska kultura potrafi określić japońską specyfikę. Polski romantyzm stanowi jedynie, w najlepszym wypadku, ,jakiś klucz” (jeden z wielu). Rela-

muzyki kompozytora. Pozostaje pytanie, dlaczego są one atrakcyjne. W artykule staram się udowodnić, że za japońskim fenomenem Chopina w rzeczywistości kryje się dorobek kulturowy i wrażliwość Japończyków - nie „surowy” geniusz Chopina. Warto także zaznaczyć, że takie pojęcia, jak na przykład smutek, emocjonalizm, melancholia czy sentymentalizm, wymykają się racjonalistycznej próbie ich zdefiniowania, zawierają niewyrażalny, wspólny dla całej ludzkości pierwiastek, a jednocześnie — paradoksalnie zarazem — ich rozumienie jest uwarunkowane kulturowo. Tematem zupełnie odrębnej publikacji naukowej mogłaby stać się analiza i interpretacja recepcji twórczości Fryderyka Chopina w różnych kulturach. Potencjał badań porównawczych pozwoliłby z całą stanowczością potwierdzić, że ta sama muzyka jest odbierana i opisywana odmiennie w poszczególnych kulturach, może cieszyć się uznaniem lub nawet być popularna, ale bynajmniej nie wszędzie urasta do rangi fenomenu.

${ }^{69}$ Termin wakon yōsai (jap. 和魂洋才) tłumaczy się jako japoński duch, zachodnia wiedza. Teoretycznie zasada wakon yōsai jest tworem epoki Meiji, w rzeczywistości jednak owo prawidło istniało właściwie od zarania japońskiej autorefleksji nad własną kulturą, z tym zastrzeżeniem, że przyjmowało inną postać. Termin Yamato damashi (jap. 大和魂), tzn. dusza Yamato (Yamato to dawna nazwa Japonii) lub Yamato gokoro (jap. 大和心), tzn. Serce Yamato, jest synonimiczny do sformułowania wakon yōsai. Różnica między wakon yōsai a Yamato damashi polega na tym, że starszy termin nie akcentuje dorobku kultury europejskiej w życiu Japończyków (ten w przeszłości nie istniał lub był znikomy). Yamato damashi lub Yamato gokoro to pojęcia akcentujące unikatowość japońskiej emocjonalności w stosunku do innych narodów. Istnieje jeszcze termin wakon kansai (jap. 和魂漢才), który najczęściej tłumaczy się jako japoński duch, chińska wiedza.

${ }^{70}$ Innym określeniem twórczego naśladownictwa jest twórcza odtwórczość. Niekiedy można też spotkać wariant odtwórcze naśladownictwo.

${ }^{71}$ Iwona KorDzIŃSKA-NAwrockA, „Kultura Japonii i jej cechy charakterystyczne”, w: Kultury świata $w$ dialogu, red. Anna Czajka-Cunico (Warszawa: Wydawnictwo UKSW, 2012), 95. 
cję Chopin-Japonia w dużym stopniu oddaje poniższy obraz. Stanie się on swoistym drogowskazem interpretacyjnym w kontekście czynionych tutaj rozważań. Dokonując sukcesywnej konceptualizacji, być może uda się uzyskać nieco klarowniejszy obraz japońskiego rozumienia Chopina:

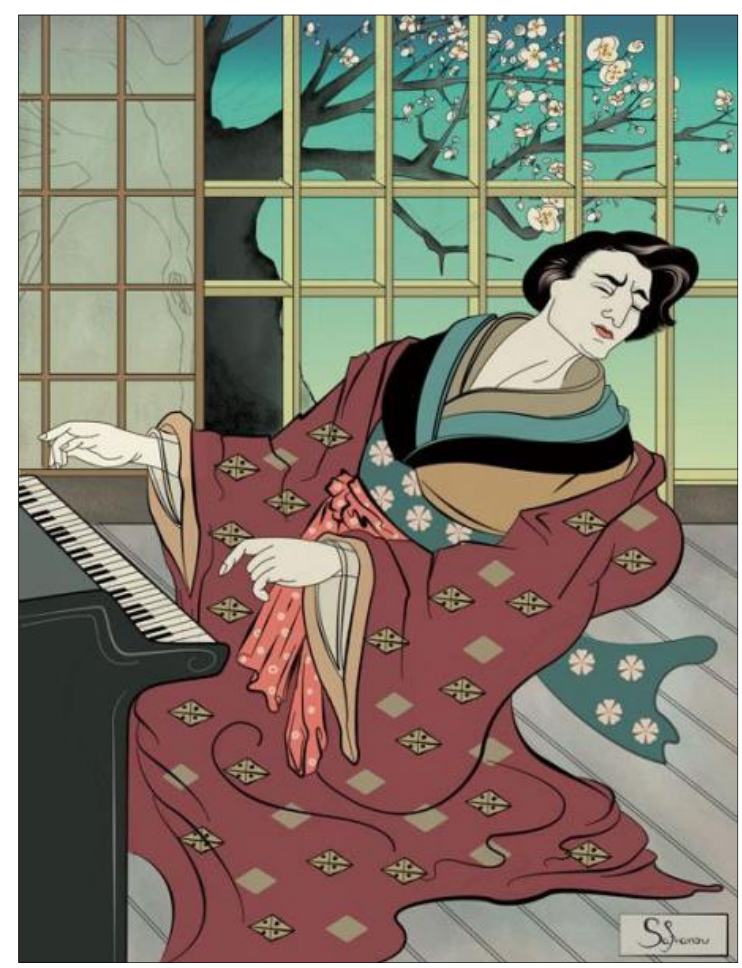

Japoński Chopin (tytuł autorski, nadany na potrzeby niniejszej pracy). Autor ilustracji: Joanna Safranow ${ }^{72}$.

Widzimy tutaj polskiego kompozytora (o japońskich rysach twarzy) odzianego w kimono. Gra na fortepianie w washitsu, tzn. w tradycyjnym pokoju w stylu japońskim. Za oknem gałęzie rozpościera drzewo kwitnącej sakury, czyli japońskiej wiśni ozdobnej, jednego z najistotniejszych symboli w kulturze japońskiej w ogóle - płatki sakury niesione wiatrem symbolizują przede wszystkim ulotność i niestałość. Wizualizacja przybiera formę $u k i y o-e^{73}$.

\footnotetext{
${ }^{72}$ Ilustracja zacytowana z artykułu Mariusza Hermy „Dlaczego Azjaci kochają Chopina (bardziej niż Polacy)", https://www.ziemianiczyja.pl/2010/04/dlaczego-azjaci-kochaja-chopina/. W wersji tego samego tekstu opublikowanej w Przekroju, tzn. w artykule pt. „Fryderyk o skośnym spojrzeniu", ilustracja znajduje się na s. 47.

${ }^{73}$ Ukiyo-e (jap. 浮世絵) można przetłumaczyć jako obraz przepływającego świata.
} 
Notabene to wizerunek Chopina, którego pozbawiono polskości i przyodziano w japońskość, wprawiono w świat rządzący się japońskimi prawidłami. Utożsamienie tego procesu z saidowskim orientalizmem ${ }^{74}$ lub amerykańskim pragmatyzmem nie byłoby jednak trafne. Proces orientalizacji zachodzi wyłącznie wtedy, gdy na podstawie świadomych — bądź nieświadomych zdeterminowanych rodzimą kulturą obserwacji stawia się fałszywe sądy normatywne o danej kulturze. Nie jest to też pragmatyzm, ponieważ owa teoria uznaje, że słuszną interpretacją jest ta, która spełnia wymogi użyteczności społecznej ${ }^{75}$. Problem moralny rodzi się momencie, gdy „użyteczna interpretacja" przeistacza się w wykładnię o danej kulturze, a jej odbiorcy nie potrafią odróżnić orientalizmu od rzeczywistości, co nagminnie się zresztą zdarza. Japońskie, niekiedy ekscentryczne, interpretacje Chopina nie aspirują do miana tekstów przybliżających polską kulturę ${ }^{76}$. Są raczej wynikiem twórczego naśladownictwa, czyli tworzą w zasadzie nowy, japoński artefakt Chopin jest zaś fundamentem tego tekstu. Pojęcie „czystej kultury” jest terminem pseudonaukowym (żadna kultura nie jest rdzennie „czysta”), w przypadku jednak Japonii niemalże cały dorobek cywilizacyjny ma swe korzenie w innej niż japońska kulturze. Dopiero po przetworzeniu, dostosowaniu danej materii do potrzeb Japończyków krystalizuje się unikatowy japoński tekst kultury. Twórcze naśladownictwo nie jest kategorią pejoratywną, przeciwnie - stanowi powód do dumy i jest poniekąd gwarantem japońskości.

Jak dowieść tezy, że kultura japońska jest źródłem fenomenu Chopina w Japonii? W jaki sposób Chopin koresponduje z japońską mentalnością oraz jak to w ogóle możliwe, że twórczość Polaka daje się przeczytać bez uwzględnienia polskości i z jednoczesnym wykluczeniem orientalizmu? Myślę, że trafne będzie odwołać się do fenomenologicznej koncepcji sztuki Romana Ingardena ${ }^{77}$, który uważał, że każda ze sztuk składa się z określonych warstw - w zależności od przypadku owe płaszczyzny mają zupełnie odmienny charakter. Dominującą w dziele warstwę określa się mianem warstwy konstytutywnej, w której obrębie zachodzi konceptualizacja rozumiana jako uzupełnianie miejsce nieokreślonych przez odbiorcę ${ }^{78}$. Przy-

\footnotetext{
${ }^{74}$ SAID, Orientalizm

${ }^{75}$ Zob. Stanley Fish, „Czy na tych ćwiczeniach jest tekst?”, w: Interpretacja, retoryka, polityka. Eseje wybrane, thum. i red. Andrzej Szahaj (Kraków: Universitas, 2002).

${ }^{76}$ Mowa tutaj o interpretacjach osobistych, tworzonych na użytek samych Japończyków. Interpretacje akademickie oczywiście mogą — choć nie oznacza to, że muszą - stawiać sobie za cel przybliżenie polskiej kultury.

${ }^{77}$ Zob. Roman IngARDEN, „O estetyce fenomenologicznej”, w: Wybór pism estetycznych, red. Andrzej Tyszczyk (Kraków: Universitas, 2006), 4-25.

${ }^{78}$ Zob. Wolfgang IsER, „Apelatywna struktura tekstów. Nieskończoność jako warunek od-
} 
padek muzyki jest o tyle nieskomplikowany, że myśliciel przypisał jej wyłącznie jedną warstwę - warstwę brzmieniową. Jest ona zarazem warstwą konstytutywną. Oznacza to, że ze wszystkich tekstów kultury muzyka jest najbardziej otwarta na różnorakie, prawomocne i równorzędne sobie, interpretacje $^{79}$. Szczyci się ich bogactwem znaczeniowym i sensotwórczym. Przypisanie znaczenia do dźwięku ${ }^{80}$ wpisuje się zatem $\mathrm{w}$ poetykę dzieła otwartego bądź nawet dzieła w ruchu.

Kontakt z muzyką ma oczywiście inny niż lektura charakter. Gdy człowiek słyszy dźwięki, uwalnia swe emocje, a dopiero potem interpretuje. Tak więc kontakt Japończyków z utworami fortepianowymi zaczyna się od emocjonalnej ekspansji uczuć, na której potem powstaje stosowna nadbudowa. Emocjonalizm jest natomiast głównym filarem kultury japońskiej, wszystko co wytworzyła jej cywilizacja, jest podtrzymywane przez emocje. Bez tej podpory nie ma Japonii, zburzenie jej to zniszczenie dorobku Japończyków. Zauważmy zatem, że już w powierzchownym kontakcie spotkanie Japończyka z Chopinem nie jest tożsame ze spotkaniem Polaka z tymże kompozytorem. Japończycy interpretują twórczość Chopina właściwymi dla siebie sposobami. Tymczasem Polak teoretycznie winien przejść przez racjonalną bramę, jego zadaniem jest oswojenie „rozbrykanych” emocji (interpretacji opartej na uczuciach przypisuje się powierzchowność) i odnalezienie idei danego utworu - trzeba określić, o czym traktuje utwór, czy mówi on o przyrodzie, czy o miłości, czy też wyraża uczucia patrioty. Dopiero uchwyciwszy „prawdziwą” ideę, nakłada się na nią odpowiednie emocje. Hierarchie - wedle założeń prototypu kulturowego — przedstawiają się więc następująco (pamiętajmy, że kultura nie rządzi się prawami matematyki, toteż pozycja określonych pierwiastków ma niebagatelne znaczenia):

$$
\begin{aligned}
& \text { Japończyk }+ \text { Chopin } \rightarrow \text { emocje }+ \text { idee } \\
& \text { Polak }+ \text { Chopin } \rightarrow \text { idee }+ \text { emocje }
\end{aligned}
$$

Kolor czerwony - emocjonalizm (nadrzędna wartość japońska)

Kolor niebieski - racjonalizm (nadrzędna wartość europejska, w tym polska)

działywania prozy literackiej”, w: Wspótczesna teoria badań literackich za granica. Antologia, t. 4, red. Henryk Markiewicz (Kraków: Wydawnictwo Literackie, 1992), 97-125.

${ }^{79}$ Zwolennicy paradygmatu strukturalistycznego krytykują fenomenologiczną koncepcję muzyki Ingardena. Pozorne bogactwo interpretacji postrzegają w ramach plejady błędnych interpretacji.

${ }^{80}$ Dźwięk ze swej natury wymyka się radykalnej konwencjonalizacji. 
Proponowana przeze mnie egzemplifikacja stanowi subiektywny, mający swoje uargumentowanie w osobistych studiach nad kulturą Japonii, wybór. Każdy z podanych „przykładów” jest poparty stosownym objaśnieniem, które jest niezbędne, aby hermeneutycznie powiązać dane pojęcie z muzyką Chopina i dostrzec tworzące się korelacje.

Elementarną wartością $\mathrm{w}$ niniejszych rozważaniach wydaje się wa (jap. 和). Słowo to thumaczy się jako harmonia, ale to uproszczenie ${ }^{81}$. Wa stanowi swoisty emblemat japońskości ${ }^{82}$. Aby zrozumieć jego znaczenie i funkcję, konieczne jest spojrzenie w stronę przynajmniej VIII wieku, kiedy to kraj zwany wakoku (jap. 倭国) przeobraził się w nowe Wakoku (jap. 和国) ${ }^{83}$. Wakoku to najstarsza nazwa Japonii, jej twórcami byli Chińczycy ${ }^{84}$. Zawarli w niej niejako swoją definicję Kraju Kwitnącej Wiśni. Kanji 倭 odnosiło się w tym kontekście do bycia podległym, posłusznym, niewielkim i mizernym, natomiast znak 国 do dzisiaj oznacza $\mathrm{kraj}^{85}$. Nietrudno domyślić się, że chińska propozycja definicji Japonii niekoniecznie przypadła do gustu jej mieszkańcom, toteż ją przemodelowali. Kanji 倭 zastąpiono ideogramem 和. Tej zmianie towarzyszyła refleksja samych Japończyków nad japońskością. Naród ${ }^{86}$ musiał zadać sobie pytania: „Co to znaczy być Japończykiem? Czym Japończycy różnią się od Chińczyków? Co jest najwyżej cenioną wartością?". Zadecydowano wówczas, że tym, co stricte uosabia japońskość, jest harmonia. Mowa tu bynajmniej nie o harmonii muzycznej ani też o harmonii znamiennej dla sztuki grecko-rzymskiej ${ }^{87}$. W pewnym skrócie możemy powiedzieć, że wa symbolizuje harmonię rozumianą w kategoriach emocjonalno-duchowych. Innymi słowy, ten termin odnosi się do przymiotów związanych z pokojem, spokojem, łagodnością, delikatnością, grzecznością, przyjaznością, umiarkowaniem, a nawet pierwiastkiem honoryfikatywności ${ }^{88}$. To nie tylko emblemat japońskości, ale też niejako jej synonim. Zobrazujmy jego moc na przykładzie współczesnego języka japońskiego.

\footnotetext{
${ }^{81}$ ADLER, The World of Kanji, 202.

${ }^{82}$ Zob. H. Gene Blocker, i Christopher L. Starling, Filozofia japońska, thum. Natalia Szuster (Kraków: Wydawnictwo Uniwersytetu Jagiellońskiego, 2008).

${ }^{83}$ Totman, Historia Japonii, 51-165.

${ }^{84}$ Pierwsze zmianki o wakoku pochodzą z fundamentalnego dla kultury chińskiej tekstu pt. Dzieje Trzech Królestw.

${ }^{85}$ ADLER, The World of Kanji, 452.

${ }^{86}$ Słowo naród pada tutaj w umownej konwencji. Nie istniało ono wszakże w dawnej Japonii.

${ }^{87}$ Harmonia wa ma cechy tożsame z harmonią grecko-rzymską, wybrane jednak podobieństwa uwidaczniają się wyłącznie w percepcji zmysłowej. Stoi za nimi natomiast inne przesłanie.

${ }^{88}$ Szczegółowe zdefiniowanie $w a$ byłoby możliwe wyłącznie poprzez analizę i interpretację aspektów, w których się ono objawia, niemniej nie to jest celem niniejszego artykułu.
} 
Obecność 和 artykułuje się w słowach nierozerwalnych z kulturą Japonii oraz pojęciach drogocennych dla Japończyków. Dla przykładu: wafuku (jap. 和服) - tzn. japońskie ubrania; wago (jap. 和語) — tzn. rdzennie japońskie słowa; washoku (jap. 和食) - tzn. japońskie jedzenie; washokki (jap. 和食器) — tzn. japońskie naczynia; wakai (jap. 和解) — tzn. pojednanie, pogodzenie; washi (jap. 和紙) - tzn. japoński papier; waka (jap. 和歌) - tj. ogólna nazwa poezji japońskiej; wafü (jap. 和風) — tzn. w stylu japońskim; heiwa (jap. 平和) - tzn. pokój (rozumiany jako przeciwieństwo wojny), harmonia; Reiwa (jap. 令和) - tj. nazwa nowej epoki w dziejach Japonii, zapoczątkowanej 1 maja 2019 r. i trwającej do dziś. Jak ma się więc wa do muzyki Chopina? Zasadniczo to pytanie retoryczne. Związek polega bowiem na tym, że Japończycy dostrzegają w jego muzyce m.in. głęboki spokój, delikatność i wysublimowanie. Reasumując, widzą w niej harmonię - harmonię wa. Myślę, że Japończycy odnoszą wa nie tylko do Chopina, ale i muzyki klasycznej w ogóle. Gdy więc Japończyk motywuje swe zamiłowanie do polskiego kompozytora argumentami pokroju: piękna fraza, piękna harmonia, piękna rytmiczność, szlachetność i delikatność, to niewątpliwie odwołuje się do kanonów wa, aczkolwiek może czynić to intuicyjnie i podświadomie.

Wróćmy teraz do naszego Japońskiego Chopina. Przypomnijmy, że artysta nosi kimono i znajduje się w washitsu. Kimono to odzież należąca do kategorii wafuku. Washitsu sygnalizuje natomiast, że kompozytor znajduje się w świecie ukonstytuowanym na standardach wa. Porzucenie garnituru na rzecz kimona jest więc symboliczną rezygnacją z polskości i przywdzianiem japońskości. Obrazowy przekaz instruuje odbiorcę, że oto Chopin gra w harmonijnej zgodzie $\mathrm{z} w a$, a jego przekaz jest wręcz stworzony dla zanurzonych w japońskości odbiorców.

Muzyka Chopina nie ogranicza się wyłącznie do wa, przeciwnie - sięga o wiele głębiej, docierając do głębokich pokładów japońskiej emocjonalności. Budzi wabi sabi ${ }^{89}$. Mimo użytego zapisu wabi i sabi nie są synonimami, każde z nich stanowi odrębną kategorię filozoficzną. Decyzja o zastosowaniu takiej formy wynika $\mathrm{z}$ faktu, że te idee zazwyczaj występują wspólnie, a sami Japończycy również posługują się przytoczonym zapisem. Fraza wabi sabi wymyka się literalnemu tłumaczeniu, nie jest ono w stanie oddać jej sensu. Przyjmijmy, że wabi wiąże się z wewnętrznym wyciszeniem, uspokojeniem umysłu, a także umiejętnością dostrzeżenia piękna w ubóstwie, skromności i prostocie. Idea uwypukla niedoskonałość, tam bowiem spoczywa szlachetna prawdziwość. Niedoskonałe, stonowane „,rzeczy pro-

\footnotetext{
${ }^{89}$ Wabi sabi (jap. 侘寂) - stosuje się również zapis przy użyciu hiragany tj. わび・さび.
} 
ste" zyskują w jej świetle nobilitację ${ }^{90}$. Paradoksalnie $s \bar{o} a n^{91}$ wydobywa większy blask niż pozłacany pałac. Sabi akcentuje natomiast samotność, smutek, kruchość, starość, melancholię i przyziemną egzystencję. Kluczowa jest dlań ulotność i niestałość, filozofia ta przypomina, że to, co się wydarzyło $^{92}$, już nigdy nie wróci, sztuką jest natomiast umiejętność dostrzeżenia, że było to przepiękne ${ }^{93}$. Andrew Juniper, chcąc zilustrować Europejczykom koncepcję wabi sabi, posługuje się alegoryczną opowieścią:

Dawno temu mężczyzna, wybrawszy się na spacer, napotkał na swej drodze wygłodniałego tygrysa, który rzucił się za nim w pogoń, zapędzając człowieka na skraj małego urwiska. Mężczyzna skoczył, chcąc uniknąć niebezpieczeństwa, i udało mu się pochwycić gałąź drzewa wyrastającego ze skarpy. Wisząc tak, dostrzegł drugiego tygrysa u stóp urwiska, wyczekującego na upadek mężczyzny. Gdy siły zaczęły człowieka opuszczać, zauważył on dziką truskawkę rosnącą w zasięgu jego ręki. $Z$ gracją wziął ją do ust $w$ pełni świadom, że będzie to ostatnia rzecz, jaką zje w swym życiu - jakże słodka była ${ }^{94}$.

W przytoczonej historii wabi uaktywnia się $\mathrm{w}$ momencie sięgnięcia po dziką truskawkę. Ten owoc $\mathrm{z}$ pewnością wpisuje się $\mathrm{w}$ ramy „rzeczy prostych". Hiperbolizuje elementarną rolę pokarmu. W zwykłych, niezagrażających życiu okolicznościach truskawka nie budziłaby żadnych niezwykłych konotacji, w obliczu jednak rychłej śmierci drobny, ubogi i niepozorny owoc staje się błogosławieństwem - choćby był bardzo kwaśny, będzie się jawił niczym słodycz. Wabi rzuca wszakże wyzwanie automatyzmowi i racjonalnej niewrażliwości na otaczający świat. Pragnie obudzić w jednostce wrażliwość pozwalającą dostrzegać piękno niedoskonałości, ubóstwa i prostoty w każdej sytuacji — nie tylko w chwilach kryzysowych ${ }^{95}$. Sabi pojawia się w refleksji nad efemerycznością ludzkiego żywota. Egzystencja człowieka symbolizuje kruchość podatną na przemijanie. Także słodki smak truskawki wkrótce przeminie. Istotą sabi jest poszerzenie spektrum sfery umysłu jednostki, ukazanie jej, że melancholia, której doświadczała i ciągle do-

\footnotetext{
${ }^{90}$ KordZIŃSKA-NAwrockA, „Kultura Japonii”, 102-106.

${ }^{91}$ Sōan (jap. 草庵) - mała, japońska chata pokryta strzechą.

${ }^{92} \mathrm{Sabi}$, podobnie jak wabi, eksponuje w głównej mierze „rzeczy proste”.

${ }^{93}$ Andrew JunIPER, Wabi Sabi. Japońska sztuka dostrzegania piękna w przemijaniu, thum. Wojciech Usarzewicz (Gliwice: Sensus, 2018), 145-160.

${ }^{94}$ Ibid., s. 1.

${ }^{95}$ Chociaż kultura europejska nie ma w swym dorobku pojęcia wabi, to obfituje w niezliczone epizody, które można byłoby opisać tą kategorią, acz niestety wrażliwość wabi w Europie uaktywniała się jedynie w skrajnie kryzysowych momentach. Jako przykład wystarczy podać rolę kromki chleba w życiu więźniów nazistowskich obozów koncentracyjnych.
} 
świadcza, to najcenniejszy skarb. Wspólne posiłki z rodziną, spotkania z przyjaciółmi, chwile zwątpienia i smutku, odrzucona miłość, kłótnie wywołujące żal, uczynki budzące chęć przeprosin, pogodzenie się z bliźnim - to wszystko było, trwa albo niebawem przeminie, należy się zorientować, że z pięknem obcuje się nieprzerwanie ${ }^{96}$.

To właśnie tę intymną, pielęgnowaną przez tradycję i wysublimowaną wrażliwość emocjonalną pobudza w Japończykach żal płynący $\mathrm{z}$ muzyki Chopina. Gdy na przykład rozbrzmiewa cykl 24 Preludiów op. 28, przywoływane są obrazy nieszczęśliwej miłości. Miłość uboga, daleka od doskonałości, przez to zaś piękna na swój sposób. Elementarna potrzeba człowieka do bycia kochanym przez drugą osobę zostaje odwzorowana wraz z żalem, za tym, co utracone. Jeśli w interpretacji uwzględnimy kontekst biograficzny autora, dzieło wybrzmi w szerszym kontekście. Nieudany związek z George Sand uaktywni niemożliwy do wyrażenia w języku tragizm: ponowne połączenie, poczucie śmierci, ważka, strach, samobójstwo, burza - są to zarówno tytuły wybranych preludiów ${ }^{97}$, jak i cenne dla Japończyków tematy. Analogicznie, gdy zagrana zostanie Etiuda op. $10 \mathrm{nr}$ 12, przed słuchaczem objawi się obraz utraconej ojczyzny. Wyrastająca z serca chęć posiadania własnego miejsca w świecie połączy się ze smutkiem po upadku powstania listopadowego ${ }^{98}$. Cierpienie Polaków zjednoczy się z tęsknotą za utraconym krajem, krajem, gdzie - jak pisał Norwid - kruszynę chleba podnoszą z ziemi przez uszanowanie dla darów Nieba.

Ponownie zwróćmy wzrok na Japońskiego Chopina. Czy dostrzegamy teraz więcej? Polskiego kompozytora nie tylko otacza wa, ale też wabi sabi. Washitsu, w którym przebywa artysta, jest ubogie i proste, pozbawione jakiegokolwiek wyposażenia z wyjątkiem fortepianu. Ten instrument określa Chopina, jego „patynowy połysk” mówi o silnym związku z sabi (patyna jest symbolem $\left.s a b i^{99}\right)$. Stonowana kolorystyka wabi odpowiada $\mathrm{z}$ kolei barwie dźwięków jego utworów ${ }^{100}$. Symbolika widocznego za oknem drzewa kwit-

\footnotetext{
${ }^{96}$ Sabi uaktywnia się w Europejczykach nierzadko na łożu śmierci (świadczą o tym przedśmiertne relacje zmarłych lub ich krewnych). W chwili śmierci człowiek podejmuje refleksje nad swym doczesnym życiem. Zdaje sobie wówczas sprawę, że doświadczył czegoś pięknego i niepowtarzalnego zarazem.

${ }^{97}$ Te tytuły nadał Hans von Bülow. Są one dość popularne i powszechnie rozpoznawalne.

${ }^{98}$ Zob. Jerzy ŁoJEK, Szanse powstania listopadowego (Warszawa: Instytut Wydawniczy PAX 1986).

${ }^{99}$ KordZiŃSKA-NAwrocKA, „Kultura Japonii”, 105.

${ }^{100}$ To stwierdzenie jest metaforą, w żaden sposób nie odnosi się do muzykologicznej koncepcji barwy poszczególnych dźwięków.
} 
nącej sakury dodaje do spreparowanego, mentalnego obrazu dramatyczną ulotność oraz przepełnioną żelem i tęsknotą niestałość.

W tym miejscu wyłania się pewien, pozornie niwelujący postawioną na początku tezę, mankament. Chodzi o aspekt interpretacjonizmu Chopinowskich utworów w odniesieniu do kontekstu biograficznego twórcy i uwarunkowań historyczno-kulturowych Polski. Jak już wspomniano, Japonia oferuje swym obywatelom barwną mozaikę stosownej do tematu literatury. Skoro zaś cieszy się ona poczytnością, prawomocne wydają się wnioski, że Japończycy jednak poszukują czegoś w polskości, próbują zgłębić jej tajniki i wydobyć wartości, które również i im są bliskie. Taka konkluzja opiera się jednak tylko na złudzeniu. Oczywiście japońscy miłośnicy kultury polskiej podejmują w tym celu odpowiednią lekturę, więcej - dążą do zrozumienia i odtworzenia oryginalnego przekazu Chopina, ale są to jednostki, z pewnością nie społeczeństwo rozumiane jako ogół. Źródła tego zjawiska powinno się upatrywać w japońskiej kulturze. Bynajmniej nie chodzi o propagowanie czytelnictwa, wyjaśnienie to byłoby zbyt proste. Odpowiedzią jest kanpekishugi (jap. 完璧 主義), tzn. perfekcjonizm. Japoński paradygmat kulturowy jest synkretyczny - łączy to, co przeciwstawne w harmonijną całość ${ }^{101}$, toteż o ile wabi sabi mówi o pięknie skrytym w niedoskonałości, o tyle kanpekishugi gloryfikuje doskonałość ${ }^{102}$. Ktoś, kto tworzy rzeczy liche bądź też oddaje się czemuś jedynie powierzchownie, jest dla Japończyków najgorszym człowiekiem, gdyż jego wytwory/działania nie są trwałe ${ }^{103}$. Perfekcyjne zamiłowanie określoną materią wywołuje pragnienie posiadania odpowiedniej wiedzy, dlatego też Japończycy kochający Chopina chłoną wszystko, co dotyczy kompozytora. $Z$ reguły nie obierają przy tym kursu wytoczonego koncepcją opisu gęstego Clifforda Geertza ${ }^{104}$. Gdy Japończyk czyta o powstaniu listopadowym, nie odtwarza jego uwarunkowań na podstawie polskiego światopoglądu, lecz spogląda na nie z perspektywy japońskiego kanonu wartości. Następnie dodaje swe interpretacje do twórczości samego Chopina i w myśl twórczego naśladownictwa kreuje w zasadzie nowy tekst kultury. Perfekcjonizm thumaczy obecność licznych kompendiów wiedzy o polskim kompozytorze. Zwraca też uwagę na jeszcze jeden, istotny fakt. Muzyka Chopina jest ponadczasowa. Tak samo jak ponadczasowa jest scheda po autorytecie. Chopin jest więc dla Japończyków autorytetem.

\footnotetext{
${ }^{101}$ KordZiŃSKa-NAwrockA, „Kultura Japonii”, 95.

102 Zob. Blocker i Starling, Filozofia japońska.

${ }^{103}$ JuniPER, Wabi Sabi, 7-46.

${ }^{104}$ Zob. Clifford GeErTz, Interpretacja kultur. Wybrane eseje, thum. Maria Piechaczek (Kraków: Wydawnictwo Uniwersytetu Jagiellońskiego, 2005).
} 
Jan Weber ${ }^{105}$ stwierdził, że japońscy wykonawcy muzyki poważnej są niczym maszyny. Bezuczuciowe skorupy niezdolne do głębokiego czucia, zdeterminowane wyłącznie do kopiowania swych mistrzów ${ }^{106}$. Teza zasługuje na krytykę, choć jednocześnie zwraca uwagę na osobliwy konflikt wartości, jaki zachodzi w obrębie japońskiej kultury. Jeśli oddzielimy samą opinię od jej pejoratywnego charakteru, pojawi się interesujący punkt zaczepienia - zrodzi się pytanie o stosunek Japończyka do autorytetu. Otóż w myśl konfucjanizmu, filozofii, na której bazuje społeczeństwo japońskie, autorytetom należy się szacunek, a przejawem perfekcjonizmu jest nieuchybiające mistrzowi naśladownictwo. Samego Chopina wprawdzie skopiować się nie da — ponieważ kompozytor nie żyje, Japończyk nie może osobiście wysłuchać jego autorskiej gry, a partytura pozostawia wiele miejsc nieokreślonych — ale zawsze można „odtworzyć” swego nauczyciela. W indywidualistycznym modelu naśladownictwo jest osobliwością drugiej kategorii, natomiast w kolektywie jest wyrazem szacunku do autorytetu, a także jedyną słuszną drogą nauki. Nadto naśladowanie nierzadko wymaga większego wysiłku i trudu aniżeli osobista ekspresja. Relacja uczeń-mistrz nieustannie odznacza się w sferach japońskiego życia. Wystarczy wspomnieć chociażby szkolnictwo, choć i ono powoli i sukcesywnie się zmienia. Tradycyjny sposób japońskiego nauczania polega na tym, że nauczyciel referuje określony materiał, natomiast uczniowie bacznie go słuchają i notują jego słowa. Komunikat przybiera formę ex cathedra, słuchacz ma słuchać, chłonąć wiedzę i naśladować autorytet (ewentualnie realizować powierzone mu zadanie), nie zaś oznajmiać, że czegoś nie rozumie, czy też prosić o dodatkowe wyjaśnienia - odpowiedzialność za przyswojenie wiedzy spoczywa wyłącznie na barkach ucznia. Co więc, gdy zamiast autorytetu nauczyciela Japończyk zetknie się z autorytetem Chopina? Konfucjanizm nakaże mu zachować pokorę wobec pianisty i spróbować najdokładniej, jak to tylko możliwe, powtórzyć jego pierwotny zamysł, z drugiej strony Nihonjin no kokoro zasugeruje wprowadzenie $\mathrm{w}$ naśladownictwo twórczego, zgodnego z pieczołowicie pielęgnowanymi potrzebami serca, pierwiastka.

Konflikt tych dwóch norm nieraz znajduje swe ujście w przestrzeni kultury. W bestsellerowej mandze pt. Shigatsu wa kimi no uso ${ }^{107}$ motyw ten

\footnotetext{
${ }^{105}$ Jan Weber (1930-1992) - polski muzykolog i krytyk muzyczny, a także publicysta.

${ }^{106}$ Niekrasz, Chopin gra $w$ duszy japońskiej, 189.

${ }^{107}$ Shigatsu wa kimi no uso (jap. 四月は君の嘘) - muzyczna shōnen manga autorstwa Naoshiego Arakawy (jap. 新川直司; Arakawa Naoshi), publikowana w latach 2011-2015. Polski tytuł tej mangi to Twoje kwietniowe klamstwo.
} 
staje się tematem przewodnim. Główny bohater Kōsei Arima jest fortepianowym wykonawcą europejskiej muzyki poważnej. Przez zwolenników swej gry nazywany jest cudownym dzieckiem, które perfekcyjnie odtwarza zamysł kompozytora, przez przeciwników - ludzkim metronomem, którego gra pozbawiona jest uczuć i nosi znamiona charakterystyczne dla maszyny, a nie istoty żywej. Abstrahując od zróżnicowanych, drażliwych opinii na jego temat, faktem jest, że Kōsei odnosi sukcesy w muzycznej karierze w każdym konkursie otrzymuje najwyższą nagrodę. Zawdzięcza to rygorystycznemu treningowi pod okiem swej matki, która zabrania synowi jakiejkolwiek improwizacji. Ostatecznie dochodzi między nimi do konfrontacji, gdy chłopak zmienia zamysł kompozytora i dedykuje utwór swej matce, ta karze go cieleśnie za niedoskonałość. Wkrótce potem kobieta umiera. Kōsei postanawia uprawiać muzykę wyłącznie w myśl norm i zasad, doświadcza jednak osobliwej przypadłości. Kiedy wykonuje utwory, przestaje słyszeć dźwięki. Muzyka, która była mu najbliższa, niejako go odrzuca. Na skutek swej dolegliwości rezygnuje z kariery pianisty. Wraca do niej dopiero pod wpływem Kaori Miyazono, dziewczyny będącej jego pozornym przeciwieństwem. Bohaterka również wykonuje muzykę klasyczną — gra na skrzypcach - niemniej nie postępuje wedle wytycznych partytury, praktycznie w każdym wykonaniu ignoruje pierwotny zamysł kompozytora. W swoją twórczość przelewa emocje ulokowane w duszy, mają one za zadanie wyrazić jej osobę. $Z$ powodu prowokacyjnej gry dziewczyna nie cieszy się przychylnością jury, jest natomiast ulubienicą audytoriów. Poglądy Kaori na muzykę mają swe źródło w doświadczeniu śmiertelnej choroby. W obliczu nadchodzącej śmierci, która niestety następuje, powzięła postanowienie trwania w prawdzie i radości. Wyraża swą emocjonalność poprzez piękne, klasyczne dźwięki. Jej styl finalnie pomaga zaleczyć rany Kōseia, ale nie zapewnia mu już takich sukcesów jak kanpekishugi.

Reasumując, podkreślono tu $\mathrm{z}$ mocą twórcze naśladownictwo i emocjonalizm, które wyrastają z Nihonjin no kokoro. Jednocześnie skrytykowano skonwencjonalizowaną, konfucjanistyczną powinność perfekcyjnego odtworzenia autorytetu. Niezależnie od tego, czy Japończyk w spotkaniu z Chopinem posłucha swego serca czy też ukorzy się przed autorytetem, i tak odwoła się do kanonu japońskich wartości. Użyje albo kanpekishugi, albo Nihonjin no kokoro.

Pozostańmy jeszcze w kręgu mangi, gdyż stanowi ona kolejny sposób na wyjaśnienie Chopinowskiego fenomenu w Japonii. Pojęcie mangi należy do grupy terminów, których zdefiniowanie nastręcza licznych trudności — ma 
prastarą, obfitującą w liczne zmiany i przeobrażenia, historię ${ }^{108}$. Na potrzeby niniejszego artykułu wystarczy, że zrozumiemy, iż ukochana przez Japończyków poetyka mangowa operuje m.in. wszechobecną ekspresją. Ta cecha jest znamienna również dla twórczości Chopina, chociaż w jego przypadku nie tyle mamy do czynienia $\mathrm{z}$ wszechobecną ekspresją, co raczej pogłębioną ekspresją. Utwory kompozytora potrafią wprowadzić słuchacza w świat harmonii uczuć, która „gęstnieje” wraz z kolejnym taktem, by wreszcie przybrać postać niepohamowanej eksplozji emocji. To Japończycy kochają prawdopodobnie najbardziej na świecie. Fryderyk Chopin niejednokrotnie w swym dorobku odwoływał się do kanonów polskiej muzyki ludowej. Konsolidował społeczeństwo poprzez zespalanie elementów kultury ludowej z kanonami kultury wysokiej. Podobnie uczyniła manga, która wprawdzie miała dworskie korzenie - przypadek emakimono ${ }^{109}$ — ale już w epoce Edo stała się jednoczącym ludzi tekstem kultury. Manga cieszyła się niespotykaną popularnością zarówno wśród mieszczaństwa, jak i „wyższych sfer”, np. uczonych, artystów czy też daimyō. Tak więc „pożeniła” ze sobą ludzi, stając na straży ugruntowanego $\mathrm{w}$ tradycji kolektywu jeszcze przed powstaniem pojęcia narodu. Nie ma natomiast Japonii bez kolektywizmu, tak jak nie ma Polski bez Mickiewicza.

Japończyk to człowiek, który nie potrafi żyć samotnie, jego istnienie utrzymuje interakcja z drugim człowiekiem. Najdobitniej dowodzi tego przejawiająca się w znaku hito (jap. 人) romantyczna etymologia istoty ludzkiej. Wprawdzie znak hito wywodzi się od piktogramu przedstawiającego ludzką sylwetkę $^{110}$, ale istnieje też jego nacechowana japońskością interpretacja. Kanji 人 składa się z dwóch kresek, z których lewa jest nieco dłuższa od prawej ${ }^{111}$. Obie symbolizują dwoje ludzi. Interpretując, człowiek jest tutaj istotą niezdolną do samoistnienia, potrzebuje bratniej duszy będącej dlań

${ }^{108} \mathrm{~W}$ odniesieniu do pojęcia manga autor niniejszego artykułu odwołuje się przede wszystkim do spostrzeżeń poczynionych przez Frederika L. Schodta, Brigittę Koyamę-Richard oraz Joannę Zarembę-Penk. Zob. Schodt, L. Frederik, Manga! Manga! The World of Japanese Comics (Tokio: Kodansha International, 1983); Brigitte Koyama-Richard, Manga. 1000 lat historii thum. Marta Domagalska (Warszawa: Wydawnictwo Naukowe PWN, 2008); Joanna ZarembAPENK, Ikonografia mangi. Wplyw tradycji rodzimej $i$ zachodnich twórców na wybranych japońskich artystów mangowych (Bydgoszcz: Kirin, 2019).

${ }^{109}$ Emakimono (jap. 絵巻物) - starojapońskie zwoje obrazowe, pierwsza postać mangi.

${ }^{110}$ ADLER, The World of Kanji, 13-14.

${ }^{111} \mathrm{~W}$ drukowanej czcionce znak wygląda na symetryczny, niemniej jest to uproszczona konwencja, akceptowalna w kilku krojach. Oryginalnie lewa kreska jest nieco dłuższa od prawej. Przy tym prawa kreska nie wyrasta z góry znaku, lecz punktu położonego nieco niżej, na lewej kresce. 
oparciem $^{112}$. Z nią będzie dzielił swe chwile tak w szczęściu, jak i w smutku. Podobnie zostało to wyrażone przez kanji 仁. Znak odnosi się do człowieczeństwa $^{113}$, ale niesie też konotacje nawiązujące do cnoty, dobrodziejstwa i prawości. Występują w nim dwie części składowe: pierwsza, po lewej stronie, składa się z dwóch kresek i wywodzi się od znaku 人, tzn. od człowieka; druga, po prawej stronie, również składa się z dwóch kresek, właściwie jest to kanji $n i$ (jap. 二), które oznacza $d w a^{114}$. Symboliczne odczytanie człowieczeństwa utożsamia je więc z kolektywną wspólnotą przynajmniej dwóch ludzi. Ekspresja, będąca spoiwem całego narodu, urasta w oczach Japończyka do wartości nadrzędnej, ponadto jest praktycznie tym samym, co uwielbiana przez naród japoński śpiewność. I wartość tę oferuje poezja ,poety fortepianu”.

Manga dopełnia konceptualizację Japońskiego Chopina. Przedstawienie ma formę ukiyo-e, a ukiyo-e to nic innego jak jedna $\mathrm{z}$ wcale nie tak dawnych postaci mangi. Pozycja kompozytora sugeruje, że gdy tylko jego palce dotkną klawiszy, obraz ożyje. Wydobędzie się z niego fala ekspresji, która obudzi wrażliwość Japończyków, począwszy od wa, a na wrażliwości mangowej skończywszy.

Podsumowując dociekanie przyczyn popularności Chopina w Japonii, warto przywołać jeszcze jeden przykład recepcji jego twórczości, może najbardziej zdumiewający. Chodzi o grę komputerową RPG pt. Trusty Bell Shopan no yume $-^{115}$ z 2007 r. Jednym z bohaterów dzieła jest Fryderyk Chopin, który w ostatnich chwilach swojego życia przenosi się do onirycznej krainy, będącej wytworem jego umysłu (zewsząd rozbrzmiewa tam jego muzyka). Spotyka on ciężko chorą kawaii ${ }^{116}$ dziewczynkę imieniem Polka (jap. ポルカ; Poruka). Postanawia jej pomóc. Ostatecznie dochodzi do powstania drużyny kompanów, złożonej z postaci równie urokliwych, co Polka. Musi ona stawić czoła rodzącemu się złu i jednocześnie pokonać spore grono potworów i przeciwników. Niniejsze streszczenie może wydawać się infantylne, ma ono jednak podkreślać obecną w grze poetykę kawaii. Ta

\footnotetext{
${ }^{112}$ ADLER, The World of Kanji, 47.

${ }^{113}$ Ibid., 294.

114 Ibid., 294.

${ }^{115}$ Trusty Bell - Shopan no yume - (jap. トラスティベル 〜ショパンの夢〜; Torasuti beru - Shopan no yume-). W Europie gra znana jest bardziej pod angielskim tytułem Eternal Sonata.

${ }^{116}$ Kawaii (jap. 可愛い) - słowo oznacza: słodki, mily, rozczulajacy, uroczy itp. Kawaii jest jednym z typów kultury japońskiej, z którego Japończycy są szczególnie dumni, gdyż nie wyrasta ono z pozajapońskich wzorców. Zob. Iwona KordzińSKA-NAWROCKA, „Japońska kultura popularna", w: Kultury świata w dialogu, red. Anna Czajka-Cunico (Warszawa: Wydawnictwo UKSW, 2012); Klaudia Adamowicz i Kamila SosnowsKa, Oblicza kawaii (Bydgoszcz: Kirin, 2018).
} 
poetyka wcale nie dąży do ośmieszenia czy skompromitowania osoby i twórczości Chopina. Przeciwnie, cała gra jest znacznie bardziej rozległa i bynajmniej nie dziecinna ${ }^{117}$. Ciekawe jest, że tak naprawdę finalnym przeciwnikiem gracza jest właśnie Fryderyk Chopin - niespodziewanie z protagonisty przeistocza się $\mathrm{w}$ antagonistę. W ostatnim epizodzie, pod wpływem obłędu, zdradza on drużynę gracza i rzuca jej wyzwanie. Kompozytor oznajmia postaciom, że ten świat należy do niego, jest jego snem, a wszyscy tutaj są jedynie wytworem jego wyobraźni. Bohaterowie sprzeciwiają się takiemu porządkowi i ostatecznie pokonują Chopina (zadaniem gracza jest o to zadbać). Po zwycięstwie ich świat nieprzerwanie trwa. Symboliczna bitwa z kompozytorem sygnalizuje, że jego twórczość w rzeczywistości nie należy do niego. Kultura japońska rzuca jej wyzwanie, zwycięsko oswaja ją i podporządkowuje własnym potrzebom. Jednocześnie zachowuje wobec niej pokorę i szacunek, co wyrażają słowa Polki, która dziękuje Chopinowi za przekazanie światu najpiękniejszego z darów - jego muzyki.

Zamysłem twórców Trusty Bell - Shopan no yume było przybliżenie osoby wielkiego kompozytora społeczności japońskich graczy. Ich dzieło należy rozumieć jako propozycję japońskiej interpretacji zarówno utworów pianisty, jak i jego własnej osoby, jego biografii. Gra szybko odniosła sukces komercyjny, i to do tego stopnia, że powstały wersje na Xboxa 360 oraz Play Station 3. Ponadto doczekała się również adaptacji mangowej. Fala popularności nie ograniczała się jedynie do Japonii, dotarła też do Ameryki Północnej i Europy. Praca Japończyków została przetłumaczona na język angielski i stała się znana w świecie Zachodu pod nazwą Eternal Sonata. Również w kręgu kultur Zachodu grę przyjęto entuzjastycznie. Dzieło nie zostało jednak przetłumaczone na język polski (społeczność polskich graczy wcale nie jest mała). Być może dla większości Polaków Chopin nie jest zbyt ważny albo też japońska interpretacja jego dorobku sytuuje się na pograniczu dopuszczalnych propozycji. Możemy sądzić, że dla konserwatywnego, polskiego chopinisty kontakt z Trusty Bell - Shopan no yume mógłby być kulturową profanacją. Ponieważ gra jest dedykowana osobom zaznajomionym z szeroko pojętą kulturą mangową, a nie „tradycyjnym” słuchaczom muzyki poważnej, jej zrozumienie przez ludzi nierozumiejących relacji międzykulturowych może być w najlepszym razie problematyczne.

${ }^{117}$ Kawaii nie jest głównym budulcem, na którym wznosi się Trusty Bell - Shopan no yume —. Dominuje kod poetyki mangowej i moe, chcąc jednak włączyć w rozważania nad umotywowaniem fenomenu kulturę kawaii, zdecydowałem się na wyeksponowanie jej względem całego dzieła. 
We współczesnym dyskursie naukowym coraz intensywniej zadaje się pytanie o tożsamość. Umiejętność zdefiniowania siebie samego pociąga za sobą rozważania na nad charakterem narodów, społeczności, jednostek, a nawet określonych tekstów kultury. Gordon Mathews w Supermarkecie kultury $^{118}$ wyjaśnia, że ten proces odbywa się na trzech poziomach. Pierwszy z nich stanowi prawo determinizmu i relatywizmu kulturowo-językowego. Tego poziomu tego nie da się w żaden sposób odrzucić, oduczyć czy choćby zakwestionować. Konstytuuje się on w stadium dziecięcym. Dziecko nie dostrzega granicy między sobą a skonwencjonalizowaną rzeczywistością, toteż kształtuje swą mentalność w zgodzie z językowym obrazem świata swojego narodu, jest on dlań czymś równie naturalnym, co przyroda. Pierwszy etap to fundament tego, co nazywamy polskością, japońskością, angielskością, niemieckością, francuskością itp. Drugi poziom Mathews nazywa shikata ga $n a i^{119}$. To sfera norm, zakazów, nakazów, powinności, kanonów wartości i obowiązujących w danej kulturze paradygmatów. Można zestawić ją z freudowską koncepcją superego lub foucaultowską koncepcją narodowego reżimu władzy. W przypadku shikata ga nai możliwe są dwie opcje: podporządkowanie się obowiązującej ideologii albo bunt i sprzeciw (człowiek najczęściej wykorzystuje obie opcje, na przykład jest posłuszny prawu państwowemu, ale nie zgadza się z obyczajem i obowiązującymi wartościami, wyznaje więc inne kanony). W rezultacie ta płaszczyzna jest gwarantem mentalnej zmienności istoty ludzkiej, gdyby bowiem materia ta była niezmienna, to na przykład Polska $\mathrm{z} X$ wieku niczym nie różniłaby się od Polski z wieku XXI. Ostatni poziom to królestwo Supermarketu kultury. Mikrokosmos, w którym reguły gry ustala rynek. Poprzez produkcję niezliczonych tekstów kultury proponuje on konsumentom atrakcyjne, dostosowane do osobistych potrzeb tożsamości. Relacja człowiek-rynek może przybrać dwa wektory. Korzystną dla Supermarketu kultury sytuacją jest podjęcie przez człowieka syzyfowej pracy, walki z determinizmem kulturowo-językowym oraz bezrefleksyjne kwestionowanie shikata ga nai (jeśli jednostka chce odrzucić/zmienić shikata ga nai, musi najpierw odbyć z nim dialog, zrozumieć je i zależnie od wyboru przyjąć jako własne albo zakwestionować i zastąpić czymś innym). Przez takie działania jednostka nie ma

\footnotetext{
${ }^{118}$ Zob. Gordon Mathews, Supermarket kultury. Globalna kultura - jednostkowa tożsamość, tłum. Ewa Klekot (Warszawa: Państwowy Instytut Wydawniczy, 2005).

${ }^{119}$ Shikata ga nai (jap. 仕方がない) znaczy nic się na to nie poradzi, nie ma na to sposobu, nic nie moge z tym zrobić, nie ma na to rady i tyle itp. W Supermarkecie kultury poziom shikata ga nai urasta do rangi koncepcji całej japońskiej kultury. Zdaniem Mathewsa kultura japońska to poniekąd kultura norm, nakazów i powinności, którym Japończyk winien się podporządkować.
} 
silnej tożsamości, sama w rezultacie nie wie, kim jest, a rynek zmienia się w nadzorcę niewolników - może proponować konsumentowi, co tylko zapragnie, gdyż ten nie będzie w stanie odrzucić jego „sezonowych” propozycji. Wektor ten można odwrócić i uczynić z Supermarketu wasala. Gdy zaakceptuje się ukształtowanego przez pierwszy poziom, kognitywistycznego ducha (soczewkę interpretowania świata) i skonfrontuje się go z shikata ga nai (ponownie można przyjmować bądź odrzucać i zastępować) kreuje się silną tożsamość. Pozwala ona na narzucenie rynkowi swoich potrzeb, prowadzi do starannie wyselekcjonowanego wyboru oferowanych przezeń dóbr. Dodając do poczynionych rozważań koncepcje Antoniny Kłoskowskiej, można rzec, że Supermarket kultury pozwala stać się człowiekowi — jeśli taka jest jego wola - kim tylko zapragnie ${ }^{120}$. Kłoskowska jest bowiem orędowniczką tezy, że świadome wybory, osobiste przekonania, kultywowane praktyki czy też własne wyobrażenia mentalne o sobie samym w rezultacie umożliwiają zmianę tożsamości narodowej.

Wektor, narzucający rynkowi wolę społeczności, przybiera japońska fascynacja Chopinem. Kultura Japonii od zarania odznaczała się silną tożsamością, potrafiła i nadal potrafi wybrać z Supermarketu kultury interesujące ją „produkty”, by następnie dostosować je do własnych potrzeb. W społeczeństwie japońskim nie obserwujemy eskalacji pragnienia przemiany w Europejczyków, w tym Polaków ${ }^{121}$ - prawdopodobnie ma to związek z konfucjanizmem, który nakazuje podporządkować się shikata ga $n a i$ - aczkolwiek nie przeszkadza to Japończykom w pożądaniu twórczości polskiego kompozytora. Jest ona starannie wybraną, spośród wielu „ofert” rynkowych, propozycją. Zaadoptowana staje się częścią japońskiej kultury. To już nie Fryderyk Chopin, lecz Furederikku Shopan ${ }^{122}$.

${ }^{120}$ Antonina KŁosKowsKa, Kultury narodowe u korzeni (Warszawa: Wydawnictwo Naukowe PWN, 2005).

${ }^{121}$ We współczesnej Japonii jednostki coraz częściej kwestionują shikata ga nai. Robią to zwłaszcza młodzi Japończycy, którzy nierzadko mają pragnienie stania się Europejczykami. Co jednak ciekawe, ten kaprys ten najczęściej ustaje wraz $\mathrm{z}$ wiekiem.

${ }^{122}$ Furederikku Shopan (jap. フレデリック・ショパン) - przetworzone przez katakanę (wedle kryteriów języka japońskiego) imię i nazwisko Fryderyka Chopina. Właśnie tak Japończycy nazywają polskiego kompozytora. 


\section{ARTYSTA BLISKI I DALEKI}

Chopin jest japońskim fenomenem, chociaż nie jest rozumiany wedle wytycznych polskości. Słuszne wydaje się jednak przypuszczać, że w jakiś sposób polska kultura jest bliska japońskiej, chociaż niekiedy można odnieść wrażenie, że Chopin bywa popularniejszy w Japonii niż w Polsce — takie wnioski wysnuwają sami polscy artyści, którzy mieli możliwość koncertowania w Kraju Kwitnącej Wiśni:

[...] Miasteczko to [...] był taki Wołomin [...]. Grałem potem Chopina w tym małym miasteczku. Była duża sala koncertowa, jak wszędzie w Japonii. Trochę się obawiałem, czy znajdą się chętni. Przyszło ponad tysiąc osób, tłoczyli się na dostawkach i stali pod ścianami. Niesamowite! Pan sobie wyobraża, żeby coś takiego wydarzyło się w Wołominie? [...] $]^{123}$

W Polsce w muzyce Chopina gustują określone kręgi odbiorców. Tymczasem w Japonii jest ona „wchłaniana” przez społeczeństwo pojęte jako ogół, choć naturalnie nadużyciem byłoby stwierdzić, że każdy Japończyk słucha Chopina. Niemniej uwielbienie dla kompozytora i tak skłania Japończyków do przemierzenia kontynentów i przybycia do artystycznej mekki sztuki chopinowskiej - mowa oczywiście o wspominanym już Międzynarodowym Konkursie Pianistycznym im. Fryderyka Chopina. Obecność japońskich uczestników jest wprawdzie intensywna, ale patrząc z innej perspektywy, żadnemu Japończykowi nigdy nie przyznano pierwszej nagrody. Nierzadko gra Japończyków odpowiadała bardziej niż jurorom gustom publiczności. Zrodziło to liczne w historii spory. Już w 1937 r., kiedy jurorzy zignorowali występ Chieko Hary, nie przyznając jej żadnej nagrody, zwrócili na siebie gniew audytorium. Konflikt zażegnano dopiero przyznaniem dla pokrzywdzonej uczestniczki nagrody publiczności z inicjatywy Stanisława Meyera ${ }^{124}$. „Wyższe sfery" zarzuciły wówczas słuchaczom uleganie emocjom i niezdolność do głębokiej interpretacji. Nie przeszkodziło to jednak pianistce w zyskaniu sympatii samego Ignacego Mościckiego. Prezydent zaprosił Japonkę na organizowane przez siebie przyjęcie, aby zaszczyciła gości swą grą ${ }^{125}$. Mimo zakwestionowania decyzji artystycznego gremium od 1937 do 2015 r. pierwsze miejsce zawsze wymykało się Japończykom z rąk. Na podium wspięli się natomiast Chińczycy (w 2000 r. konkurs zwyciężył Li Yundi) oraz

\footnotetext{
${ }^{123}$ Za: Niekrasz, Chopin gra w duszy japońskiej, 125.

${ }^{124}$ Ibid., 86.

${ }^{125}$ Ibid., 88.
} 
Koreańczycy (w 2015 r. zwycięstwo odniósł Cho Seong-jin). Z uwagi na specyficzne stosunki polityczno-kulturowe między Japonią a Chinami i Koreą Południową owe decyzje były dla Japończyków wielkimi porażkami. Niejako dowodzą też one, że polskim specjalistom bardziej podoba się chiński i południowokoreański sposób interpretacji Chopina aniżeli propozycje japońskie. W środowisku chopinistów nieustannie trwa debata, czy polski sposób odczytania utworów kompozytora może rościć sobie prawo do nadrzędności.

Vivaldi, Mozart, Beethoven - tak znamienite osobistości zostały w Japonii przyćmione przez geniusz Chopina. Dlaczego spośród wszystkich kompozytorów Japończycy umiłowali sobie właśnie Polaka? Czy to wyłącznie dlatego, że jego twórczość odpowiada temu, co wypracowała kultura Japonii? Muzyka Chopina ma biało-czerwoną barwę. Biel i czerwień to kolory tak polskiej, jak i japońskiej flagi. Obie flagi są jednak różne, inaczej formują barwy i wykorzystują różne ich odcienie. Polska wersja tworzy dwa symetryczne pasy, z kolei kompozycja japońska przedstawia czerwone słońce na białym tle. Kilkaset lat przed Rousseau ${ }^{126}$ japoński buddyzm Zen zrodził ciekawą koncepcję. W jej założeniu kultura czyni świat dualistycznym, zaprogramowanym przez ustalone wzorce $^{127}$, a zadaniem człowieka poprzez dyscyplinę - jest niejako oduczenie się nabytej kultury ${ }^{128}$. Pozwala to na powrót do esencji człowieczeństwa, pierwotnej prawdziwości. Może stąd bierze się takie uwielbienie dla muzyki Chopina w Japonii. Bodźce dźwiękowe prawdopodobnie były najstarszymi sygnałami, z którymi zmierzył się człowiek pierwotny - musiał je oswoić, przysposobić i zinterpretować. Chopin potrafi natomiast dotrzeć do zapomnianych już dzisiaj struktur myślowych z dawnych czasów oraz na nowo je rozbudzić, zwłaszcza w kulturze odwołującej się do emocjonalizmu.

\section{BIBLIOGRAFIA}

Adamowicz, Klaudia, i Kamila Sosnowska. Oblicza kawaii. Bydgoszcz: Kirin, 2018.

AdLer, Alex. The World of Kanji: A Book to Learn 2136 Japanese Characters through Real Etymologies. CreateSpace Independent Publishing Platform, 2018.

Bernardyn, Piotr. „Japonia: Geniusz udomowiony”. Tygodnik Powszechny. Kwartalnik Chopinowski 02 2010, nr 31: 10.

${ }^{126}$ Zob. Jean-Jacques Rousseau, Rozprawa o pochodzeniu i podstawach nierówności między ludźmi, tłum. Henryk Elzenberg (Warszawa: PWN, 1956).

${ }^{127}$ Juniper, Wabi Sabi, 7-68.

${ }^{128} \mathrm{~W}$ świecie dorobku humanistyki europejskiej nie jest to w żaden sposób możliwe. 
Blocker, H. Gene, i Christopher L. Starling. Filozofia japońska. Tłum. Natalia Szuster. Kraków: Wydawnictwo Uniwersytetu Jagiellońskiego, 2008.

FIsH, Stanley. „Czy na tych ćwiczeniach jest tekst?”. W: Interpretacja, retoryka, polityka. Eseje wybrane. Tłum. i red. Andrzej Szahaj, 59-80. Kraków: Universitas, 2002.

Geertz, Clifford. Interpretacja kultur. Wybrane eseje. Tłum. Maria Piechaczek, Kraków: Wydawnictwo Uniwersytetu Jagiellońskiego, 2005.

Gordon, Andrew. Nowożytna historia Japonii. Tłum. Iwona Merklejn. Warszawa: Państwowy Instytut Wydawniczy, 2010.

Herma, Mariusz. „Fryderyk o skośnym spojrzeniu”. Przekrój 2010, nr 6: 46-49. Dostępny również jako „Dlaczego Azjaci kochają Chopina (bardziej niż Polacy)”. Ziemia Niczyja. Dostęp 19.10.2020. https://www.ziemianiczyja.pl/ 2010/04/dlaczego-azjaci-kochaja-chopina/.

INGARDEN, Roman. „O estetyce fenomenologicznej”. W: Wybór pism estetycznych, red. Andrzej Tyszczyk, 4-25. Kraków: Universitas, 2006.

ISER, Wolfgang. Apelatywna struktura tekstów. Nieskończoność jako warunek oddziatywania prozy literackiej. W: Wspótczesna teoria badań literackich za granica. Antologia. T. 4, red. Henryk Markiewicz, 97-125. Kraków: Wydawnictwo Literackie, 1992.

Japonia okresu Meiji, Od tradycji ku nowoczesności, red. Beata Kubiak Ho-Chi. Warszawa: Nozomi, 2006.

Japonia w oczach Polaków. Państwo-społeczeńśtwo-kultura, red. Józef Włodarski i Kamil Zeidler. Gdańsk: Wydawnictwo Uniwersytetu Gdańskiego, 2009.

Juniper, Andrew, Wabi Sabi. Japońska sztuka dostrzegania piękna w przemijaniu. Tłum. Wojciech Usarzewicz. Gliwice: Sensus, 2018.

KawaI, Hayao. Japanese Psyche: Major Motifs in the Fairy Tales of Japan. Tłum. Sachiko Reece. Woodstock, CT: Spring Publications, 1997.

KŁoskowsKa, Antonina. Kultury narodowe u korzeni. Warszawa: Wydawnictwo Naukowe PWN 2005.

Kofin, Ewa. Ich stowa. Wrocław: Atut Oficyna Wydawnicza, 2009.

KordZIŃSKA-NAwrockA, Iwona. „Japońska kultura popularna”. W: Kultury świata w dialogu, red. Anna Czajka-Cunico. Warszawa: Wydawnictwo UKSW, 2012.

KordziŃSKA-NAWROCKA, Iwona. „Kultura Japonii i jej cechy charakterystyczne”. W: Kultury świata w dialogu, red. Anna Czajka-Cunico. Warszawa: Wydawnictwo UKSW, 2012.

Koyama-Richard, Brigitte. Manga. 1000 lat historii. Tłum. Marta Domagalska. Warszawa: Wydawnictwo Naukowe PWN, 2008.

KuYAMA, Kōichi. „O pracach translatorskich Yukio Kudo autora japońskiego przekładu 'Pana Tadeusza' ". Wiek XIX: Roczniki Towarzystwa Literackiego imienia Adama Mickiewicza" 2 (44) 2009: 198-216.

ŁoJEK, Jerzy. Szanse powstania listopadowego. Warszawa: Instytut Wydawniczy PAX, 1986.

MACHIDA, Bożena, Małgorzata SuzuKi. „Soplicowo zimą - wywiad z Yukio Kudō”, 2001. Strona polska w Japonii. Dostęp 19.10.2020. http://www.klikdotsystems.jp/stronapolska/files/ wywiad.html.

Maslow, Abraham, Motywacja i osobowość, tłum. Józef Radzicki, Warszawa: Wydawnictwo Naukowe PWN, 2006.

MAtHEws, Gordon. Supermarket kultury. Globalna kultura-jednostkowa tożsamość. Tłum. Ewa Klekot. Warszawa: Państwowy Instytut Wydawniczy, 2005.

Niekrasz, Lech Zdzisław. Chopin gra w duszy japońskiej. Warszawa: Rytm, 2010. 
OKumura, Shizuka. „Chopin w Japonii. O współczesnych gustach muzycznych Japończyków i ich miłości do Polskiego Kompozytora”, 2017. Meakultura. Muzyka, edukacja, artyści. Dostęp 19.10.2020. http://meakultura.pl/artykul/chopin-w-japonii-o-wspolczesnych-gustachmuzycznych-japonczykow-i-ich-milosci-do-polskiego-kompozytora-1731.

Ōshima, Kazumi. "Recepcja twórczości Chopina w Japonii”, 2008. Tłum. Jerzy Ossowski. Chopin.pl. Dostęp 19.10.2020. https://www.chopin.pl/np/w_japonii.pl.html.

„Prof. Akiko Kasuya: Polacy i Japończycy pobodnie czują i myślą”, 2019. Dzieje.pl. Portal historyczny. Dostęp 19.10.2020. https://dzieje.pl/kultura-i-sztuka/prof-akiko-kasuya-polacy-ijaponczycy-podobnieczuja-i-mysla.

Rousseau, Jean-Jacques. Rozprawa o pochodzeniu i podstawach nierówności między ludźmi. Tłum. Henryk Elzenberg. Warszawa: PWN, 1956.

SAID, Edward. Orientalizm. Tłum. Monika Wyrwas-Wiśniewska. Poznań: Wydawnictwo Zysk i S-ka, 2005.

Schodt, L. Frederik. Manga! Manga! The World of Japanese Comics. Tokio: Kodansha International, 1983

SEKIGUCHI, Tokimasa. Eseje nie całkiem polskie. Kraków: Universitas, 2016.

TAKASAKA, Haruka. „Harmonia, ulotność, Nintendo...”. Tłum. Wioletta Laskowska-Smoczyńska. Tygodnik Powszechny. Kwartalnik Chopinowski 04. Vivace 2010, nr 41: 8-9.

Totman, Conrad. Historia Japonii. Tłum. Justyn Hunia. Kraków; Wydawnictwo Uniwersytetu Jagiellońskiego, 2009.

Ugrešlć, Dubravak. Kultura karaoke. Tłum. Dorota Jovanka Ćirlić. Kraków: ha!art, 2013.

ZaJĄcZKowski, Ryszard. „Japońska Polska. Kulturowy wizerunek Polski w Japonii”. Zeszyty Naukowe KUL 60 (2018), nr 2 (242): 381-398.

ZAJĄCZKOWSKI, Ryszard. „Literatura polska w Japonii”. Roczniki Kulturoznawcze 7 (2016), nr 3: $147-169$.

ZAREMBA-PENK, Joanna. Ikonografia mangi. Wptyw tradycji rodzimej i zachodnich twórców na wybranych japońskich artystów mangowych. Bydgoszcz: Kirin, 2019.

\section{FRYDERYK CHOPIN I FUREDERIKKU SHOPAN \\ — RECEPCJA MUZYKI FRYDERYKA CHOPINA W KULTURZE JAPOŃSKIEJ}

\section{Streszczenie}

Niniejszy artykuł koncentruje się na próbie odkrycia istoty fenomenu japońskiej fascynacji osobą i twórczością Fryderyka Chopina. To zjawisko zostało już fragmentarycznie zilustrowane w publikacjach naukowych. Dotychczas jednak nie udzielono odpowiedzi na pytanie, dlaczego recepcja Chopina jest w Japonii od lat tak intensywna. Autor artykułu stawia tezę, że źródeł japońskiego fenomenu Chopina należy szukać w kulturze japońskiej, nie zaś w japońskim zainteresowaniu kulturą polską. Kategorie wa, wabi, sabi, kanpekishugi, kawaii i manga pozwalają naświetlić tę kwestię z właściwej perspektywy. Za sprawą „twórczej odtwórczości” Japończycy przekształcają muzykę polskiego kompozytora i dostosowują ją do własnych upodobań. Na skutek tego procesu powstaje japońska „nowa jakość”, która nie jest tożsama z pierwotnym kontekstem. Fryderyk Chopin zyskuje w Kraju Kwitnącej Wiśni nowe japońskie oblicze.

Słowa kluczowe: Fryderyk Chopin; Japonia; Chopin w Japonii; muzyka japońska; muzyka klasyczna; twórcza odtwórczość. 


\section{FRYDERYK CHOPIN AND FUREDERIKK SHOPAN FRÉDÉRIC CHOPIN'S MUSIC RECEPTION IN JAPANESE CULTURE}

\section{S u m m a ry}

This article focuses on an attempt to discover the essence of the phenomenon of Japanese fascination with the person and work of Frédéric Chopin. This phenomenon has already been partially illustrated in scientific publications. So far, however, no answer has been given to the question why Chopin's reception has been so intense in Japan for years. The Author of the article puts forward the thesis that the sources of the Japanese phenomenon of Chopin should be sought in Japanese culture, not in the Japanese interest in Polish culture. The categories wa, wabi, sabi, kanpekishugi, kawaii, and manga put this into perspective. Thanks to the "creative reproductiveness," the Japanese transform the music of the Polish composer and adapt it to their own preferences. As a result of this process, a Japanese "new quality" arises, which is not identical to the original context. Frédéric Chopin gains a new Japanese face in the Land of the Rising Sun.

Key words: Frédéric Chopin; Japan; Chopin in Japan; Japanese music; Classical music; creative reproductiveness. 